\title{
Oxidative and Nitrosative Stress in Age-Related Macular Degeneration: A Review of Their Role in Different Stages of Disease
}

\author{
Caterina Toma ${ }^{1,+} \mathbb{D}$, Stefano De Cillà ${ }^{1,2,+}$, Aurelio Palumbo ${ }^{1}$, Divya Praveen Garhwal ${ }^{3}$ and Elena Grossini ${ }^{3, *(\mathbb{D})}$ \\ 1 Eye Clinic, University Hospital Maggiore Della Carità, 28100 Novara, Italy; \\ caterina.toma@maggioreosp.novara.it (C.T.); stefano.decilla@med.uniupo.it (S.D.C.); \\ aurepa95@gmail.com (A.P.) \\ 2 Department of Health Sciences, University East Piedmont "A. Avogadro", 28100 Novara, Italy \\ 3 Laboratory of Physiology and Experimental Surgery, Department of Translational Medicine, \\ University East Piedmont "A. Avogadro", 28100 Novara, Italy; divya.praveen@uniupo.it \\ * Correspondence: elena.grossini@med.uniupo.it; Tel.:+39-0321-660526 \\ + These Authors equally contributed to the present paper.
}

Citation: Toma, C.; De Cillà, S.;

Palumbo, A.; Garhwal, D.P.; Grossini,

E. Oxidative and Nitrosative Stress in

Age-Related Macular Degeneration:

A Review of Their Role in Different

Stages of Disease. Antioxidants 2021,

10, 653. https://doi.org/10.3390/

antiox10050653

Academic Editor: Marialaura Amadio

Received: 18 March 2021

Accepted: 21 April 2021

Published: 23 April 2021

Publisher's Note: MDPI stays neutral with regard to jurisdictional claims in published maps and institutional affiliations.

Copyright: (C) 2021 by the authors. Licensee MDPI, Basel, Switzerland. This article is an open access article distributed under the terms and conditions of the Creative Commons Attribution (CC BY) license (https:/ / creativecommons.org/licenses/by/ $4.0 /)$.

\begin{abstract}
Although the exact pathogenetic mechanisms leading to age-related macular degeneration (AMD) have not been clearly identified, oxidative damage in the retina and choroid due to an imbalance between local oxidants/anti-oxidant systems leading to chronic inflammation could represent the trigger event. Different in vitro and in vivo models have demonstrated the involvement of reactive oxygen species generated in a highly oxidative environment in the development of drusen and retinal pigment epithelium (RPE) changes in the initial pathologic processes of AMD; moreover, recent evidence has highlighted the possible association of oxidative stress and neovascular AMD. Nitric oxide (NO), which is known to play a key role in retinal physiological processes and in the regulation of choroidal blood flow, under pathologic conditions could lead to RPE/photoreceptor degeneration due to the generation of peroxynitrite, a potentially cytotoxic tyrosine-nitrating molecule. Furthermore, the altered expression of the different isoforms of NO synthases could be involved in choroidal microvascular changes leading to neovascularization. The purpose of this review was to investigate the different pathways activated by oxidative/nitrosative stress in the pathogenesis of $\mathrm{AMD}$, focusing on the mechanisms leading to neovascularization and on the possible protective role of anti-vascular endothelial growth factor agents in this context.
\end{abstract}

Keywords: age-related macular degeneration; oxidative stress; nitrosative stress; mitochondrial function; autophagy; anti-vascular endothelial growth factor agents

\section{Introduction}

Age-related macular degeneration (AMD) is a complex multifactorial retinal degenerative disease primarily affecting the macula and progressively leading to irreversible central vision loss. It is the first cause of blindness in the Western world, with an estimation of up to 18.6 million people being affected by the blinding stages of the disease by 2040 worldwide [1], though a consistent decline in blindness secondary to AMD has been observed from 1990 to 2020 thanks to the introduction of anti-vascular endothelial growth factor agents (VEGF) [2]. In 2013, the Beckman Initiative for Macular Research Classification Committee proposed a new classification of AMD, in which progression of disease was defined by the size of drusen, presence of retinal pigment epithelium (RPE) changes and occurrence of choroidal neovascularization (CNV), mainly driven by the over-expression of VEGF, and/or geographic atrophy (GA) in the late stages [3]. The Consensus on Neovascular AMD Nomenclature (CONAN) Study Group, based on information given by more recent imaging technologies such as optical coherence tomography (OCT) and OCT-angiography, proposed a new terminology for neovascularization and atrophy secondary to AMD [4]. 
In particular, the new term macular neovascularization (MNV) was introduced to replace the term $\mathrm{CNV}$, as recent findings have shown that neovascularization (NV) not always originates from the choroid as previously reported [4].

The exact pathogenetic mechanisms leading to AMD are still not fully understood; however, it is well known that AMD is a multifactorial disease with multiple genetic and environmental factors contributing to its onset and progression [5-11]. Aging, the main risk factor for $\mathrm{AMD}$, and other predisposing factors (e.g., cigarette smoking, high fat diet, excessive light exposure and genetic variants involving genes of the complement cascade such as Complement Factor H) significantly increase oxidative stress in the retina, leading to the excessive formation of reactive oxygen species (ROS), peroxidative processes and chronic inflammation [12-20], with an inability of the physiologic anti-oxidant local defensive mechanisms to counteract the accumulation of toxic metabolites, cellular debris and free radicals [21-23].

The present review will concentrate on the role of oxidative and nitrosative stress in the initiation and progression of AMD, with particular attention on the mechanisms leading to the formation of neovascularization in the context of AMD and the possible protective role of anti-vascular endothelial growth factor (VEGF) agents in this context.

\section{The Role of Choriocapillaris (CC)/Bruch's Membrane (BrM)/Retinal Pigment Epithelium (RPE)/Photoreceptor Complex in Different Forms of AMD}

The maintenance of a physiologic relationship between the different components of the $\mathrm{CC} / \mathrm{BrM} / \mathrm{RPE} /$ photoreceptor complex is of primary importance to preserve its correct functioning and the breakdown of this equilibrium is involved in the changes occurring in AMD [24].

Summarizing the different contributions of these components to the local homeostasis, photoreceptors (and cones, in particular, which are the predominant photoreceptors in the macular region) are highly metabolically active cells rich in mitochondria (in their inner segments) and capable of phototransduction [25]. Their building and metabolism is supported by the RPE, which supplies nutrients for this purpose and plays a key role in maintaining the retinal homeostasis, serving as a limiting transport system between the outer retina and choroid $[24,26]$ and as part of the waste degrading and recycling system of the retina, and photoreceptors in particular [24,27]. RPE cells are anatomically strictly connected to the $\mathrm{BrM}$, which, thanks to its strategic location, regulates the diffusion of molecules between the RPE and choroid. Lastly, the CC, the capillary component of the choroid, provides all metabolic needs, including oxygen $\left(\mathrm{O}_{2}\right)$, to photoreceptors from serum [25]. It emerges from this brief overview how the impairment of even a single component of the complex can become detrimental to the functioning of the whole system.

Even if it is well-established that the entire complex is altered in AMD, doubts remain on which could be the first component to be altered in the pre-clinical and early stages of disease. Photoreceptor degeneration and death, RPE changes (pigmentary changes, reduction in melanosomes and cell density and increase in lipofuscin granules), BrM thickening and formation of deposits and reduced density and diameter of the CC are all aspects seen in AMD. Post-mortem analyses performed with a specific image analysis technique on the human eyes of subjects affected by AMD allowed the correlation between the loss of RPE and the loss of CC [28], and a linear relationship between them was detected in GA [24]. Moreover, areas of RPE loss with underlying preserved CC were found at the edges of GA, suggesting that RPE might be the primarily affected site in GA [24,29]. In contrast, in neovascular AMD (nAMD) areas of significant CC reduction surrounding the $\mathrm{NV}$ were observed in association with areas of intact RPE, in this case indicating that the first trigger in nAMD could be the vascular impairment caused by an ischemic and/or inflammatory insult with secondary RPE dysfunction [24,30-35]. In a recent post-mortem study on human donor eyes, Lutty et al. showed the presence of significant CC dropout (measured as percent vascular area) in the macular region in eyes affected by early AMD compared to aged control eyes [36]. Moreover, they found, in two out of seven eyes with early AMD, the presence of hypercellular structures breaking through the BrM, which were 
considered as early forms of NV [36]. Seddon et al. had previously detected early NV in $40 \%$ of eyes with intermediate AMD [37]. As all areas of NV formation demonstrated an overlying complete RPE monolayer, it was hypothesized that CC dropout could lead to a hypoxic insult to RPE cells with overexpression of pro-angiogenetic factors, in particular VEGF, and a consequent stimulus to neo-angiogenesis [36-38].

\section{Oxidative Stress as the First Trigger for AMD Initiation}

Non-neovascular AMD is the most frequent form of AMD and is defined by the presence of drusen, the first clinically detectable sign of the impairment of the $\mathrm{CC} / \mathrm{BrM} / \mathrm{RPE} /$ photoreceptor complex in AMD (Figure 1). Different in vitro models have been used to investigate the association of oxidative stress with the development of AMD and current knowledge supports the hypothesis of oxidative stress as the initial trigger for AMD pathogenesis [39-41]. Exposure of cultured primary fetal human RPE cells (hRPE) and ARPE-19 cells (a transformed cell line from the RPE of a 19-year-old male donor) to oxidative stress has been shown to increase the expression of several proteins involved in the processes of apoptosis, inflammation and DNA repair demonstrated in the pathologic changes typical of AMD [42-48]. Moreover, the use of hRPE cultures derived from adult stem cells from the RPE exposed to tert-butylhydroperoxide as a model of chronic oxidative stress demonstrated the upregulation of several proteins commonly found in drusen (such as $\alpha \mathrm{B}-,, \beta \mathrm{B} 1-,, \beta \mathrm{B} 2-$-, $\beta \mathrm{S}$ - and $\beta \mathrm{A} 4$-crystallins, amyloid precursor protein, complement component 9 and VEGF-A) [49]. In addition, the development of subretinal deposits and RPE changes have been demonstrated in knock-out mouse models for antioxidant and toxic response genes such as the superoxide dismutase family (SOD-1 and 2), nuclear factor erythroid-derived 2-like 2 (NFE2L2 and Nrf2) and aryl hydrocarbon [50-54].

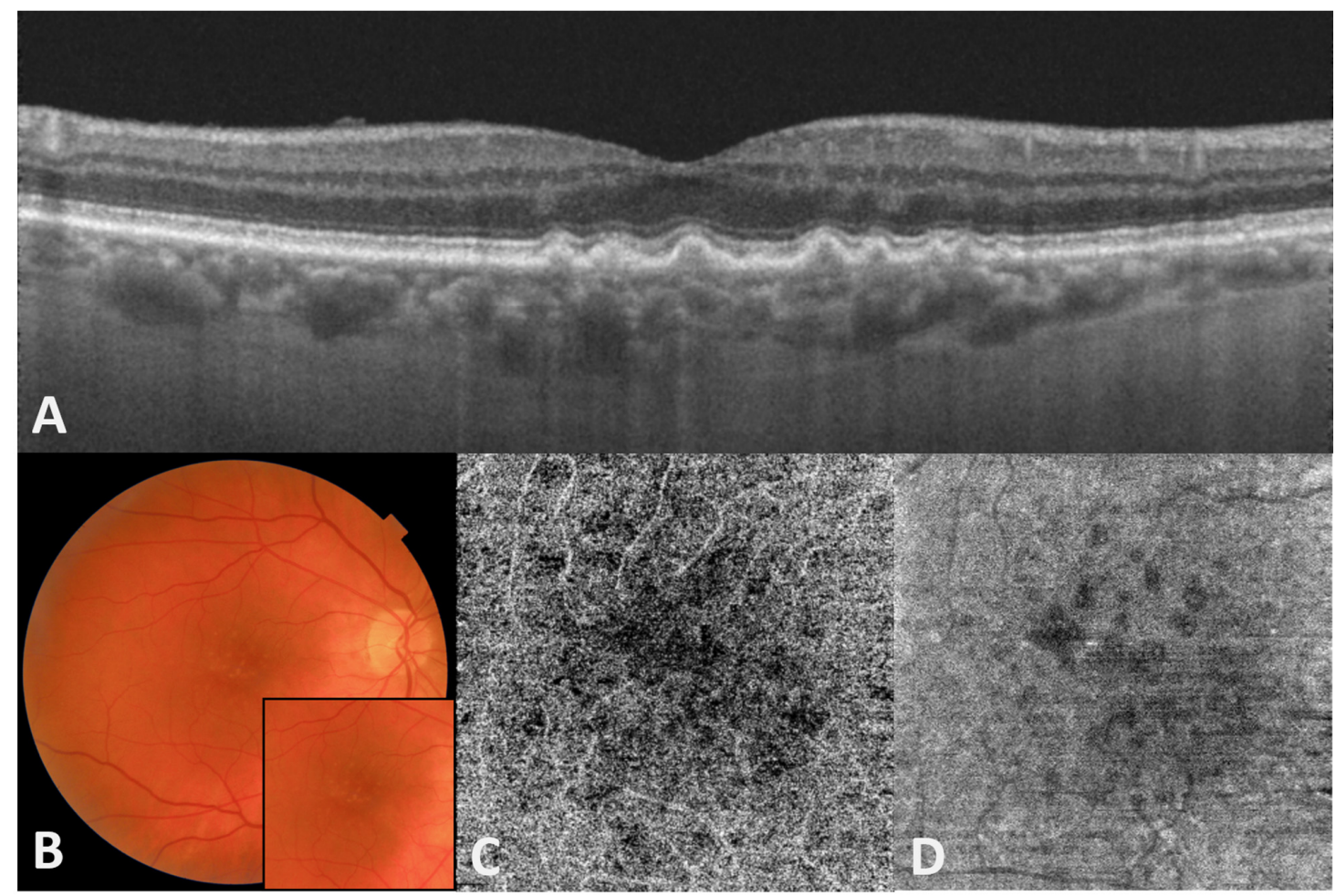

Figure 1. Right eye of an 86-year-old male patient with macular drusen. (A) Optical coherence tomography (OCT) B-scan centered on the fovea showing multiple drusen and no signs of exudation. (B) Color fundus photography of the posterior pole showing partially confluent small and intermediate drusen in the macular region. No hemorrhages or other signs of exudation are present. (C) OCT-angiography $4.5 \times 4.5 \mathrm{~mm}$ macular slab segmented at the choriocapillaris level showing multiple areas of low signal due to reduced perfusion but no signs of macular neovascularization. (D) Corresponding en-face structural choriocapillaris image showing defects underlying drusen. 
Retinal cells are particularly susceptible to oxidative damage due to their extremely high $\mathrm{O}_{2}$ consumption and metabolic activity and to their constant exposure to light and ultraviolet (UV) radiation; in particular, exposure to visible light (especially of shorter wavelength) has been associated with damage to photoreceptors and RPE cells (as UV radiation is mainly absorbed by the cornea and the lens) consequent to the local generation of high amounts of ROS, such as superoxide anion, hydroxyl radical, hydrogen peroxide and singlet oxygen, as byproducts of retinal metabolism [55-61]. Even if in moderate concentrations ROS play an important role in the regulation of protein function in the retina, at higher levels (as those produced and not counterbalanced during pathologic processes such as AMD) they have detrimental effects on cellular health, leading to the impairment of local homeostasis with the consequent activation of pathologic intra and intercellular pathways. Photoreceptors, cones in particular, and RPE cells are particularly susceptible to oxidative damage, being nonproliferative postmitotic cells lacking any system to detect DNA damage in their cell cycle checkpoints [62,63]. The main sources of ROS in AMD consist of: lipid peroxidation of phospholipid decosahexaenoic acid (DHA), one of the major components of photoreceptor membranes [64,65]; absorption of light by lipofuscin and the other photosensitizers present in the retina [66]; phagocytosis of the outer segments of photoreceptors by RPE cells with the consequent generation of hydrogen peroxide $\left(\mathrm{H}_{2} \mathrm{O}_{2}\right)$ from NADPH oxidase in the phagosome; or $\beta$-oxidation of lipids in peroxisomes $[23,67]$ (Figure 2). There are two different mechanisms hypothesized to be involved in lipofuscin-mediated ROS generation: the first is direct via interaction with light [68]; the second is mediated by the production of N-retinylidene-N-retinylethanolamine (A2E) [69]. Moreover, lipofuscin has also been demonstrated to be capable of decreasing the activity of lysosomal and antioxidant enzyme systems in the RPE [70]. Lipid peroxidation highly reactive end-products, such as 4-hydroxylnonenal (4-HNE), malondialdehyde (MDA), oxidized nucleotides and carboxyethyl pyrrole (CEP), have been demonstrated to be associated with drusen formation and RPE atrophic modifications in both human and animal eyes [19,71-80]. Lipid peroxidation activates the nuclear factor kappa-light-chain-enhancer of activated B cells (NF- $\mathrm{KB}$ ) signaling pathway with the consequent release of different pro-inflammatory cytokines, creating a pro-inflammatory environment that could eventually contribute to AMD progression [81]. Recently, Kim et al. used a murine AMD model (induced by the injection of hydroperoxy-octadecadienoic acid-HpODE, a peroxidized lipid, into the subretinal space) to study the pathologic processes involved in the degeneration of the retina and choroid and demonstrated an early increase in the expression of markers of oxidative stress (and lipid peroxidation in particular as demonstrated by the high levels of 4-HNE and MDA) and inflammation, followed by the infiltration of inflammatory cells into the subretinal space and neural retina and concomitant RPE and photoreceptors damage [82]. The expression of some oxidative stress response genes, such as nicotinamide adenine dinucleotide phosphate (NADPH) oxidases (NOX and DOUX) genes, was upregulated as early as 2 and 5 days after HpODE injection [82].

All these processes trigger the activation of different pathways in many cell types, both of the retina and choroid, involved in chronic inflammation (e.g., through the activation of the NF-kB pathway) [83-86], impairment of autophagy, activation of the complement system and hypoxia $[87,88]$, with the consequent further release of ROS and the initiation of a vicious cycle and progressive amplification of the pathologic events that result in cell death and AMD progression [83-86,89]. In ARPE-19 cells, the accumulation of excessive amounts of ROS triggers the activation of the nod-like receptor family pyrin domain containing 3 (NLRP3) inflammasome, an important regulator of the secretion of different pro-inflammatory cytokines, through the increase in lysosomal membrane permeabilization, the activation of the mitogen-activated protein kinase (MAPK) and NF- $\mathrm{kB}$ signaling pathways, and probably also local activated microglial cells [90-92]. The mechanisms leading to RPE cell death induced by oxidative stress are still poorly understood [93] and, even if apoptosis has been the most studied mechanism of programmed cell death (PCD) in the RPE [94], more recent studies have suggested that other forms of PCD, such 
as necroptosis (a form of regulated necrosis) and ferroptosis (a form of iron-dependent non-apoptotic programmed necrosis), could be involved in AMD pathogenesis [93,95-99].

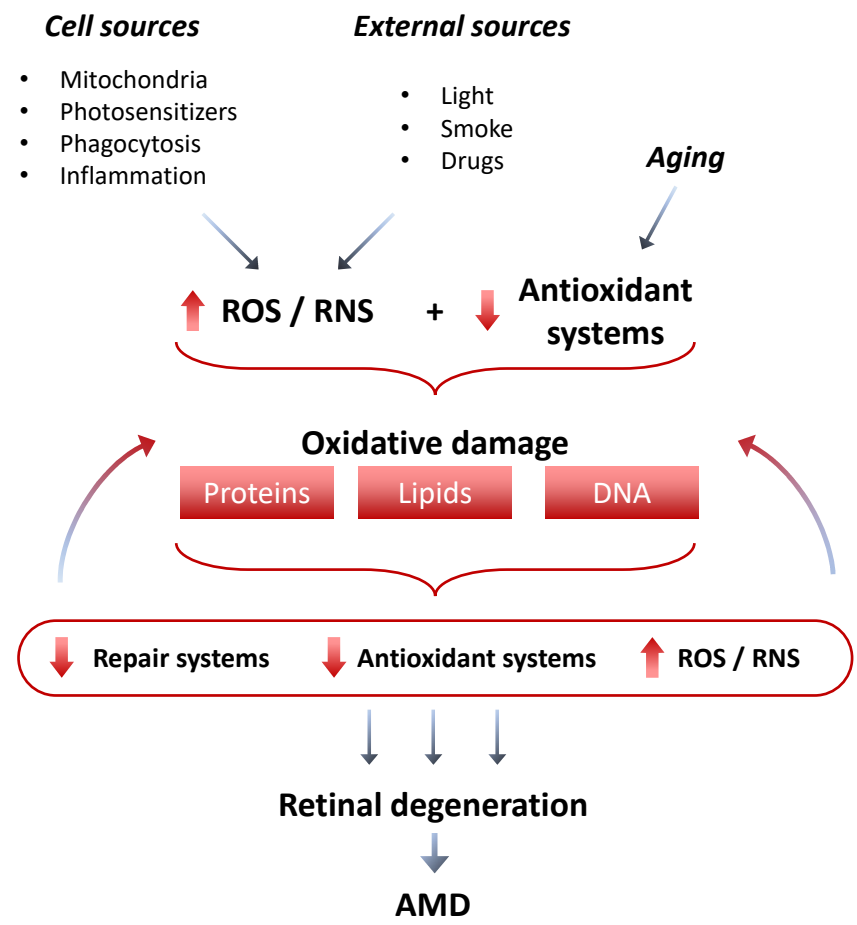

Figure 2. Mechanisms at the basis of oxidative damage in AMD. ROS: reactive oxygen species; RNS: reactive nitrogen species; AMD: age-related macular degeneration.

\subsection{The Role of Mitochondria in ROS Production and Oxidative Damage in the Early Phases of AMD}

Mitochondria are suggested to play an important role in AMD pathophysiology. High numbers of mitochondria are present in metabolically active cells like RPE cells, while their number decreases with age and disease [100,101]. Decreased mitochondrial number, function and ATP production have been demonstrated in RPE cells isolated from human AMD eyes [102] and previous reports showed mitochondrial depolarization, with reduced energy production and an increase in Cytochrome $C$ release and ROS generation, to precede RPE cell death caused by peroxidation [103-105], thus highlighting the existence of a link between mitochondrial impairment, RPE degeneration and an unbalanced cellular redox system. Mitochondrial electron transport chain (ETC) complexes are a major source of ROS as a byproduct of respiration [106-108] and, under pathologic conditions involving ETC components, ROS production and leakage into the cytoplasm are significantly increased and not balanced by the local anti-oxidative stress metabolism [109]. Ultrastructural damage, decrease in number and decreased levels of mitochondrial heat shock protein 70 have been observed in mitochondria of eyes with AMD [110,111]. Mitochondrial DNA (mtDNA) is particularly susceptible to oxidative damage due to the absence of protective histones and intrones and to its high transcription rate with a less effective repair system than nuclear DNA [62], and previous studies documented mtDNA early damage in the RPE of patients with AMD compared to age-matched controls [112,113]. mtDNA damage was found in regions encoding for subunits of the ETC (and in particular in genes that code for the complex I-NADH complex, and III-cytochrome complex) and in the D-loop, the site of initiation for mtDNA transcription and replication of a strand [107,113-115]. Different hypotheses exist on the possible mechanisms responsible for the progressive accumulation of mtDNA damage in AMD, including decreased activity of antioxidant enzymes and/or mtDNA repair proteins and impaired clearance capacity [116]. Mitochondrial damage leads to the impairment of the process of oxidative phosphorylation (since all genes encoded by mtDNA are involved in oxidative phosphorylation), with a consequent further 
increase in ROS generation and the initiation of a vicious cycle $[117,118]$. mtDNA damage was specifically found in RPE cells and not observed in photoreceptors [113], and it was hypothesized that this could be due to the different pathways involved in energy production in the two cell types [116].

\subsection{Impairment of Autophagy and Oxidative Damage}

Autophagy is a lysosome-mediated catabolic process that contributes to cellular homeostasis, degrading and removing organelles such as mitochondria with damaged mtDNA (mitophagy), aggregated proteins, lipid droplets and exogenous pathogens [62,119], and its dysregulation has been demonstrated to increase cellular susceptibility to oxidative stress [120]. Beclin-1 and microtubule-associated protein 1 light chain 3 (LC3) are considered reliable biochemical markers of autophagy activation and are used to evaluate the role of autophagy in AMD [121,122]. The reduced efficiency of autophagy in RPE cells, with the consequent reduced removal of damaged proteins and organelles, has been identified as a crucial event in the initiation of AMD changes in models selectively deficient for autophagy-related genes (such as Atg-5 and 7), with formation and accumulation of drusen-like deposits resembling those seen in dry AMD [120,123-126]. Lipofuscin is believed to further reduce autophagy efficiency by blocking lysosomal enzymes and increasing lysosomal membrane permeability, with the consequent release of the potentially toxic content of lysosomes (redox-active iron, lytic enzymes) and ROS generation [127]. Further confirmation of the role played by impaired autophagy in AMD came from Golestaneh et al.'s research, in which the authors described an increase in the number of autophagosomes and reduced levels of autophagic flux along with increased production of ROS and impaired mitochondrial activity in cultured hRPE of AMD human donors compared to healthy controls [128]. The autophagy response to oxidative stress dynamically modifies under different conditions; Mitter et al. used ARPE-19 cells exposed to $\mathrm{H}_{2} \mathrm{O}_{2}$ for 3-24 h and 14 days to study the cellular response under both acute and chronic oxidative stress and observed an initial increased autophagic activity followed by a reduction in autophagic flux [120].

\section{Antioxidant Mechanisms in the Retina}

Under physiologic conditions, many enzymatic and non-enzymatic antioxidants act to prevent cellular damage and death induced by ROS accumulation. Under pathologic conditions, the cellular capacity to neutralize ROS decreases due to a loss of efficiency of the antioxidant systems (with reduced production of ROS scavengers and other antioxidants) parallel to an over-production of ROS [112,129]. Brown et al. demonstrated that the lack of the mitochondrial antioxidant enzyme SOD2 in the RPE induced high cellular oxidative stress with consequent RPE and photoreceptor dysfunction [130]. Cellular strategies intended to limit oxidative damage include the restriction of the site and action of oxidant-producing enzymes to regions adjacent to the target, e.g., $\mathrm{H}_{2} \mathrm{O}_{2}$ transport is limited by the presence of aquaporin channels [131]; moreover, ROS have a short half-life and their production is time-limited to the oxidant burst [22]. Moreover, oxidative stress induces the upregulation of specific antioxidant enzymes, such as manganese superoxide dismutase (MnSOD) and catalase as a compensatory response to a highly oxidative environment [132,133]. A number of transcription factors are involved in the regulation of antioxidant systems and, between them, nuclear factor erythroid-2 related factor 2 (Nrf2, also known as NFE2L2) and peroxisome proliferator-activated receptor gamma coactivator1 (PGC-1) play key roles in the activation of cellular antioxidant defense systems.

\section{The p62/Keap1/Nrf2 and PGC-1 Pathways}

The Nrf2 and PGC-1 pathways are critical pathways in both the activation of autophagy and the protective response to oxidative stress [123]. Nrf2 is a transcription factor that regulates cellular homeostasis, protecting cells from oxidative damage and preventing ROS-induced retinal cell death [134-136]. Under physiologic conditions, Kelch-like ECH- 
associated protein 1 (Keap1) degrades Nrf to prevent its translocation from the cytosol to the nucleus [136]. Under conditions of oxidative stress, Nrf2 translocates into the nucleus and initiates the transcription of antioxidant genes, such as catalase or SOD, and autophagyrelated genes [137-140]. Wang et al. demonstrated that in eyes affected by early AMD, Nrf immunolabeling is decreased in damaged RPE cells and increased in morphologically normal RPE cells, supporting the hypothesis that, under conditions of high oxidative stress, the Nrf pathway is impaired and not sufficient to prevent cellular damage [141]. The development of drusen and RPE changes were demonstrated in knock-out murine models for Nrf, however the impairment of this signaling pathway was not sufficient to induce progression to the advanced stages of disease, such as nAMD [52]. The scaffolding adaptor protein p62/sequestosome 1 (SQSTM1) pathway, specifically involved in the autophagy of protein aggregates and mitophagy and acting as a bridge with the ubiquitin-proteasome system (the other major system of cellular clearance), could activate the Nrf2 pathway by binding to Keap1 and promoting its degradation to block its interaction with Nrf2 [142-144], and this further highlights the close interplay between mechanisms involved in autophagy and the response to oxidative stress. PGC- $1 \alpha$, PGC-1 $\beta$ and PGC-1-related coactivators form a defense system against oxidative stress by upregulating the expression of antioxidant genes, such as SOD2 and thioredoxin 1 (TRX1), and the loss of function of this system can contribute to AMD initiation, increasing the formation of ROS by mitochondria and the accumulation of mitochondrial damage [142]. A knock-out murine model for PGC-1 $\alpha$ exposed to a high-fat diet developed drusen-like deposits and RPE cell and photoreceptor degeneration, along with evidence of reduced autophagy flux [145], thus implying that the PGC-1 pathway is also involved in autophagy regulation against oxidative damage. Felszeghy et al. used Nrf2/PGC-1 $\alpha$ double knock-out mice to study the role of autophagy in the development of dry AMD and observed high levels of oxidative stress markers, such as 4-HNE, damaged mitochondria and large autolysosomes in the RPE cells, along with an increase in p62/SQSTM1, Beclin-1 and LC3B [146]. We already reported evidence on how reduced autophagic activity could lead to cellular damage in AMD in the previous paragraph (see Section 3.2.).

\section{Oxidative Stress and Late Neovascular AMD}

In the previous paragraphs, scientific evidence of the role of oxidative stress as a trigger for the initial stages of AMD was reported and discussed. Even if the exact mechanisms leading to neovascularization in the late stages of AMD are not fully elucidated, it is hypothesized that oxidative stress could be involved even in this case. In the past, it was debated whether oxidative stress could directly promote NV or if it is only involved in drusen formation and progressive RPE, and photoreceptor dysfunction and death, which finally lead to NV [147]. However, recent evidence suggests that the association of oxidative stress, hypoxia and impaired autophagy may be a stimulus for VEGF secretion in RPE cells, thus contributing to induce the development of new vessels, which are the hallmark of nAMD [62,148-150].

Dong et al. used a murine model deficient in SOD1 to study how a compromised antioxidant defense system could contribute to create a pro-angiogenic environment in the subretinal space, with the consequent development of NV, and they observed that Sod1 ${ }^{-/-}$ mice had a significantly lower expression of VEGF and more NV compared to Sod ${ }^{+/+}$ mice [147]. ROS have been shown to induce the expression of VEGF189, a splice variant of VEGF-A, in cultured hRPE cells exposed to $\mathrm{H}_{2} \mathrm{O}_{2}$ [151]. More recently, mitochondrial dysfunction has also been hypothesized to play a role in promoting neovascularization in AMD [152]. Enzymes belonging to the NOX family (NOX1, NOX2 and NOX4 in particular) have been proposed as one connection between ROS generation and VEGF release in the human choroid $[153,154]$. NOX homologues are major sources of ROS in the vasculature, with the consequent proliferation and migration of endothelial cells, activation of the transcription factor NF- $\mathrm{KB}$ and increased expression of VEGF, directly or through hypoxiainducible factor 1-alpha [154-158]. VEGF in turn can stimulate the generation of ROS 
through the activation of Rac1, a subunit of NOX, and this interplay creates a vicious cycle that progressively increases the release of both VEGF and ROS leading to endothelial cell proliferation and migration and the formation of new vessels $[153,159,160]$.

Previous reports observed an increased peroxidation activity with disease progression from early stages to nAMD [161]. The activation of 12/15-lipoxygenase, the enzymes catalyzing lipid peroxidation, has been shown to increase ROS generation, the expression of NOX2 and vascular permeability (via activation of the VEGF-R2 signaling pathway) [162]. Recently, Zor et al. measured serum levels of MDA in the samples of 30 patients with nAMD and detected significantly higher values of this biomarker compared to age-matched controls [163], confirming previous studies that observed serum MDA levels 14.9\% higher in patients with nAMD compared to controls [80]. Moreover, low-dose MDA treatment for $48 \mathrm{~h}$ on ARPE-19 cells was demonstrated to induce VEGF expression and modifications in autophagic activity, whereas the MDA-induced VEGF increase was reduced by 3-methyladenine and ammonium chloride, an autophagy and a lysosomal inhibitor, respectively; therefore, the authors speculated that MDA might act on VEGF secretion through the autophagy-lysosomal pathway [80]. In particular, Bergmann et al. detected a significant increase in the isoforms VEGF 121 and VEGF 165 after the exposure of ARPE-19 cells to MDA or HNE [164]. Ye et al. further investigated the correlation between MDA administration and VEGF secretion in vivo in a murine model, and observed that the injection of MDA in the vitreous cavity of mouse eyes significantly increased VEGF levels in the RPE/choroid and the volume of laser-induced NV compared to controls injected with phosphate-buffered saline [80]. These findings were further confirmed in a following study showing a direct correlation between MDA serum levels and neovascular lesion area in AMD patients [165]. In their murine model to study the effects of oxidative stress (induced by the injection of HpODE, see Section 3) on retinal and choroidal tissues, Kim et al. observed a progressive accumulation of activated microglia and inflammatory cells in the subretinal space from day 5 to day 20, followed, at day 20, by the appearance of new vessels breaking through BrM into the retina, along with a significant increase in VEGF levels in RPE cells and in the choroid [82].

Animal models exposed to acute light damage (LD) are also frequently used to study retinal degeneration induced by oxidative stress [166,167], and Tisi et al. recently used this model to investigate the correlation between LD and nAMD in vivo, finding a significant upregulation of VEGF-A and other pro-angiogenic factors (such as basic fibroblast growth factor, bFGF) and subsequent early NV (starting 7 days after light exposure), along with the detection of long-term activated microglia surrounding the new vessels; therefore, they suggested that microglial cells might be implicated in the process of neoangiogenesis in AMD [167]. Other recent studies have postulated that microglia could be a target of oxidative stress, triggering a vicious cycle of inflammation and cellular degeneration [168]; blockade of the microglial adenosine receptor $\mathrm{A}_{2 \mathrm{~A}}$ has been associated with a reduction in the levels of ROS and concomitant retinal degeneration, and a dose-dependent increase in microglia activation (along with an increase in pro-inflammatory cytokines, inducible nitric oxide synthase and HSP70) was observed after injection of $\mathrm{H}_{2} \mathrm{O}_{2}$ in an in vitro retinal model $[169,170]$.

\section{Nitric Oxide and Nitrosative Stress Role in AMD}

Nitric oxide (NO) is a gas-signaling molecule synthesized as a byproduct of the reaction of the conversion of L-arginine to L-citrulline catalyzed by three different isoforms of NO synthase (NOS) [171]: the constitutive and calcium-dependent neuronal NOS (nNOS), the inducible and calcium-independent NOS (iNOS) and the endothelial NOS (eNOS) isoforms [172]. While the nNOS and eNOS isoforms are constitutively expressed and play a role as regulators of physiological phenomena, the inducible isoform iNOS is thought to be involved in cytotoxic and inflammatory functions [173-175]. Therefore, NO could exert cellular protective or harmful effects depending on its concentration and on the balance between the activity of constitutive/inducible isoforms of NOS [174]. 
In the retina, NOS isoforms can be found in retinal neurons, RPE, amacrine and ganglion cells, nerve fibers and photoreceptors and evidence has emerged about the role of $\mathrm{NO}$ as a mediator of physiological, and possibly pathological, processes in all the abovementioned retinal structures $[174,176]$. In this context, small amounts of eNOS-derived NO could act as a potent vasodilator and play a key role in the physiological regulation of ocular blood flow; furthermore, in the RPE, NO contributes to the function of the phagocytosis of rod outer segments and to the regulation of VEGF gene expression [177-179]. However, under conditions of oxidative stress, reactive nitrogen species (RNS), such as peroxynitrite, nitrogen dioxide, dinitrogen trioxide and peroxynitrous acid, produced by high levels of NO, can induce cellular damage as a result of reactions with proteins and DNA [180,181]. In particular, $\mathrm{NO}$ in high concentrations reacts with superoxide anions $\left(\mathrm{O}_{2}{ }^{\bullet-}\right)$ to produce peroxynitrite $\left(\mathrm{ONOO}^{-}\right)$, a potentially cytotoxic tyrosine-nitrating molecule, which could induce the accumulation of protein aggregates between photoreceptors and RPE cells, with final photoreceptor degeneration [177-179]. Even if the exact role of NO in AMD pathogenesis is still not clear, recent studies have hypothesized that changes in NO levels and NOS activation/expression in AMD patients could be involved in the modulation of choroidal perfusion, which could contribute to the development of AMD [177].

\section{Nitric Oxide and Nitrosative Stress in Late Neovascular AMD}

An important role of $\mathrm{NO}$ in the late stages of AMD, in particular in NAMD, has been documented, as nitrosative stress is thought to play a role in the microcirculatory changes observed in the choroid of patients with nAMD $[175,182]$. The large amount of iNOS-derived NO could be, at least in part, responsible for the vascular damage in the retina observed in AMD, as a consequence of increased peroxinitrite generation [174]. The imbalance between NO and peroxinitrites could affect choroidal perfusion by both reducing the availability of NO and increasing RNS production, with consequent vasoconstriction and cellular damage. Moreover, it has been demonstrated that, under pathologic conditions, oxidative stress is able to convert eNOS from a NO-producing enzyme to a superoxide-producing enzyme in a reaction that causes the reduction in glutathione levels (a process known as NOS uncoupling), thus turning from being a "beneficial" NOS isoform to a detrimental one, and further contributing to increase cellular oxidative damage (Figure 3) [183,184]. In the retina, eNOS is constitutively expressed in the endothelial cells and smooth muscle cells of retinal arteries and capillaries, but its presence has also been detected in photoreceptors, horizontal cells, bipolar and ganglion cells, amacrine and Müller cells $[177,185,186]$, nNOS in the outer and inner plexiform layers and in bipolar, amacrine and ganglion cells [177,187-190]. Both eNOS and nNOS isoforms have been shown to play an important role in physiologic ocular functions (such as phototransduction and the regulation of retinal blood circulation) and in the onset of retinal diseases [174,191-193]. iNOS expression is induced in the inner retina and outer segments of photoreceptors by inflammatory conditions [194-196]. In the choroid of aged healthy subjects, eNOS was found to be prevalently expressed in the CC, while nNOS was expressed in the nuclei of RPE cells and in perivascular nerve fibers surrounding arteries and arterioles [177]. Bhutto et al. studied the localization of NOS isoforms in 22 human donor eyes with AMD (both non-neovascular and nAMD) by immunohistochemistry and compared their distribution to that observed in age-matched controls; they detected a significant decrease in nNOS and eNOS in the retina and choroid of AMD patients and postulated that reduced concentrations of NO may be associated with vasoconstriction and blood flow decrease (secondary to the loss of CC and perivascular nerve fibers) in the submacular choroid in AMD [177]. In the same study, the authors performed a sub-analysis on eyes with nAMD, investigating the differences in NOS isoform expression in the area occupied by new vessels and in the underlying and adjacent choroid. They observed high levels of eNOS and iNOS in correspondence with new vessels and a low expression in the underlying and adjacent choroid, thus confirming the involvement of NO in nAMD [177]. Previous studies demonstrated that $\mathrm{NO}$ is a mediator of angiogenesis through the regulation of different 
proangiogenic factors, including VEGF [197], and the VEGF proangiogenic effect requires the activation of eNOS with the consequent release of NO [198-200]. It has also been shown that iNOS could be a promoter of neovascularization and, based on the observations on a murine model knock-out of the NOS gene and on cell cultures with a down-regulated iNOS/NO/VEGF signaling pathway, researchers suggested that inhibition of nNOS and iNOS expression may reduce the rate of formation of MNV [201-203]. Therefore, it was hypothesized that NOS activity may induce NV through increased VEGF expression under hypoxic conditions $[177,193]$.

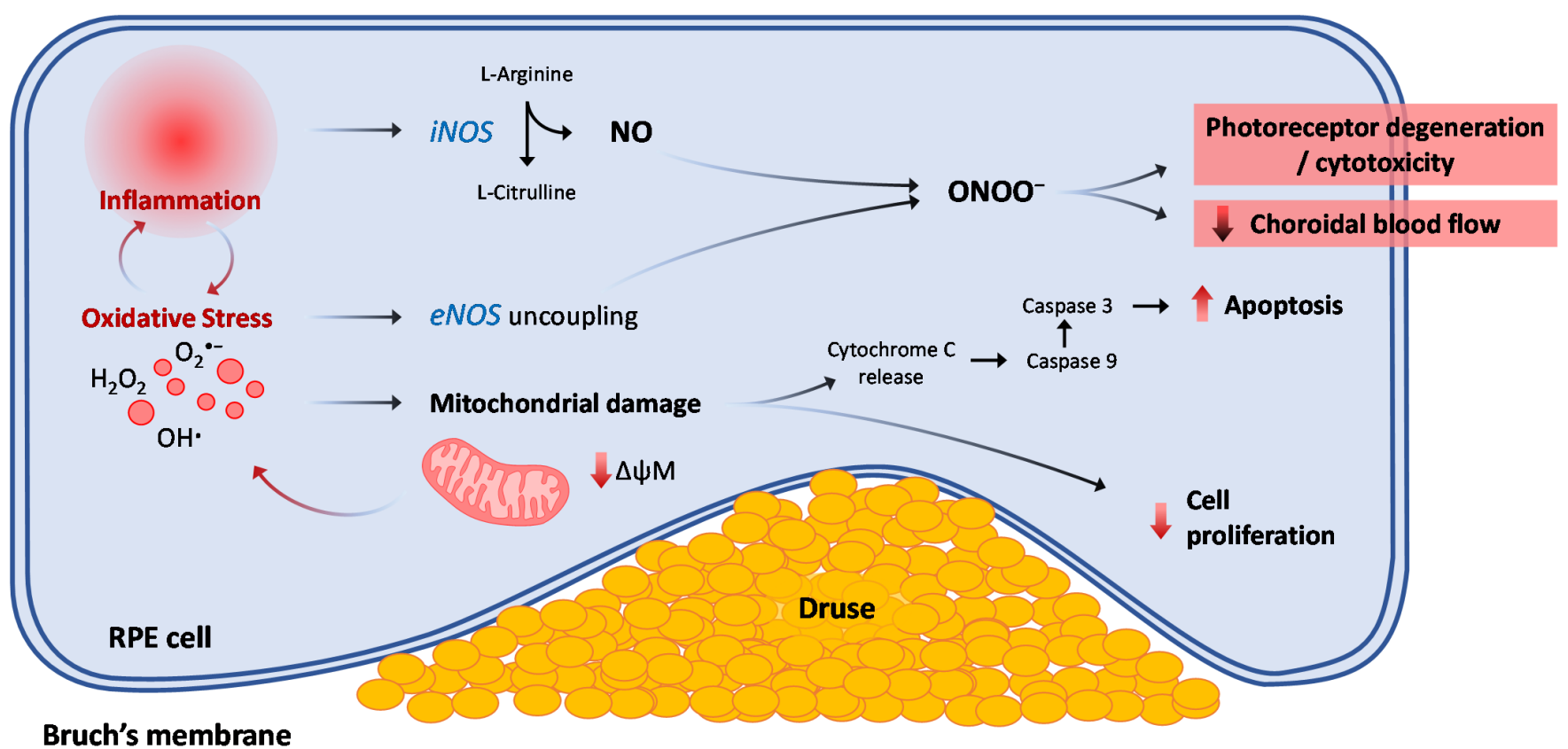

Figure 3. Schematic representation of the intracellular mechanisms leading to progressive changes observed in AMD as a consequence of oxidative and nitrosative stress. iNOS: inducible nitric oxide synthase; eNOS: endothelial nitric oxide synthase isoform; $\mathrm{ONOO}^{-}$: peroxinitrites; ROS: reactive oxygen species; $\Delta \psi \mathrm{M}$ : mitochondrial membrane potential; AMD: age-related macular degeneration.

\section{The Role of Anti-VEGF Agents against Oxidative/Nitrosative Stress}

Anti-VEGF agents are currently the standard of care for exudative nAMD (Figure 4) [204]; however, their role against oxidative damage is still poorly investigated.

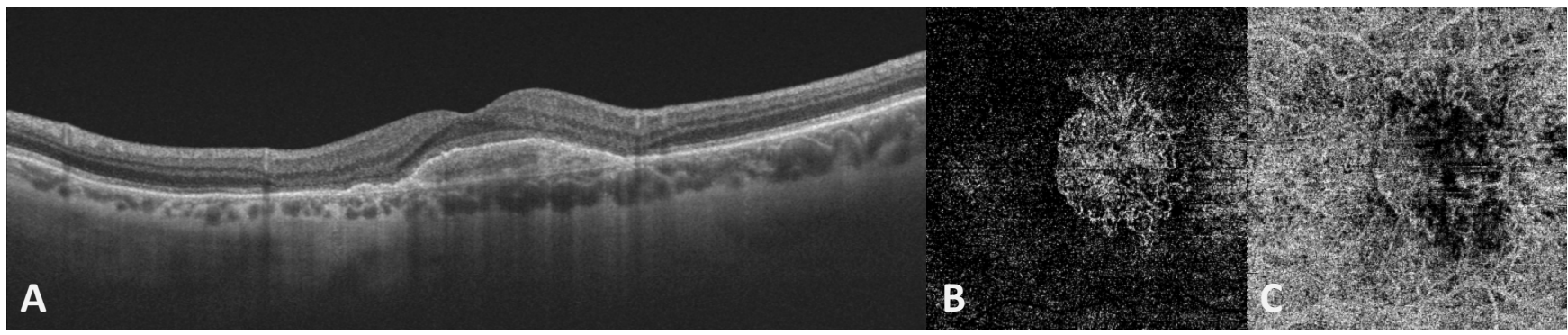

Figure 4. Left eye of a 72-year-old female patient with neovascular AMD previously treated with 10 intravitreal injections of anti-VEGF. (A) Optical coherence tomography (OCT) B-scan centered on the fovea showing a subfoveal fibrovascular PED with no signs of active exudation. (B,C) OCT-angiography (OCT-A) $4.5 \times 4.5 \mathrm{~mm}$ macular slab segmented at the outer retina (B) and choriocapillaris $(\mathbf{C})$ level showing the presence of MNV. AMD: age-related macular degeneration; PED: pigment epithelium detachment; MNV: macular neovascularization. 
In a recent study, our group examined the effects of Aflibercept and Ranibizumab on oxidative stress in vitro on cultured ARPE-19 cells and showed that both agents (used at the same concentrations obtained in the human eye after intravitreal injection) were positively involved in the modulation of cell viability and mitochondrial function in RPE cells, acting on mechanisms mediated by NO release and the regulation of autophagy both under physiologic conditions and after exposure to $\mathrm{H}_{2} \mathrm{O}_{2}$ [205]. In particular, under conditions of oxidative stress, Aflibercept and Ranibizumab were able to reduce NO release induced by $\mathrm{H}_{2} \mathrm{O}_{2}$, by modulating the activity or the expression of the eNOS and iNOS isoforms [205]. For the reasons explained in the previous paragraph (see Section 6), balancing NO release could be helpful to preserve choroidal blood flow, regulate the process of the phagocytosis of photoreceptor outer segments and reduce peroxinitrite generation and release.

Contradictory evidence exists in the literature on the effects of anti-VEGFs on mitochondrial function; in fact, while Malik et al. did not find any beneficial effect on mitochondria at clinical doses (and detrimental effects at higher doses) [206], Sheu et al. proposed that anti-VEGF agents could be protective in mitochondria, preserving their energetic metabolism, and might consequently reduce cellular damage caused by oxidative stress [207]. The findings by our group confirmed this second hypothesis, demonstrating a positive effect of both Aflibercept and Ranibizumab on mitochondrial membrane potential, accompanied by the inhibition of apoptosis as shown by the reduction in apoptotic markers, such as Cytochrome $C$ and Caspase 9 [205]. As previous data have shown a clear association between RPE dysfunction and compromised mitochondrial function (see Section 3.1.), the positive effect exerted by anti-VEGFs on mitochondrial membrane potential could be of significant clinical relevance. In the same study, the presence of 3 methyladenine, an inhibitor of autophagy, reduced the positive effect of anti-VEGFs on mitochondrial membrane potential, whereas rapamycin, an activator of autophagy, potentiated this effect, thus suggesting that the beneficial action of Aflibercept and Ranibizumab on mitochondria and cellular survival may be mediated, at least to some extent, by the autophagy pathway [205]. It is also noteworthy that both anti-VEGF agents, in addition to preventing the fall of cell viability and preserving mitochondrial membrane potential, were also able to increase cell proliferation and migration [205] (Figure 5), in contrast with some in vivo studies reporting evidence that anti-VEGF treatment can potentially increase the rate of development of macular atrophy in AMD, though data in the literature on this topic are controversial and not conclusive [208-213]. Changes in the ocular microenvironment or effects of anti-VEGF agents on retinal cells other than RPE, as well as in their cross-talk in vivo, could be at the basis of these discrepancies. Therefore, the effects of anti-VEGFs on co-cultures of ARPE-19 cells and human umbilical vascular endothelial cells (HUVEC) were investigated in a following study; this model was created in order to examine the cross-talk between RPE and vascular endothelial cells in the maintenance of the external blood retinal barrier, under conditions of oxidative stress induced by treatment with $\mathrm{H}_{2} \mathrm{O}_{2}$ [214]. The results obtained showed that both Aflibercept and Ranibizumab inhibited the release of $\mathrm{NO}$ and ROS induced by $\mathrm{H}_{2} \mathrm{O}_{2}$ and modulated the activation and expression of eNOS and iNOS isoforms in RPE cells; moreover, the presence of a NOS inhibitor decreased the protective effects elicited by anti-VEGFs on RPE cells. Those findings further supported the hypothesis that NO might play an important role as a mediator of the protective effect of the anti-VEGFs on cellular survival [214]. 


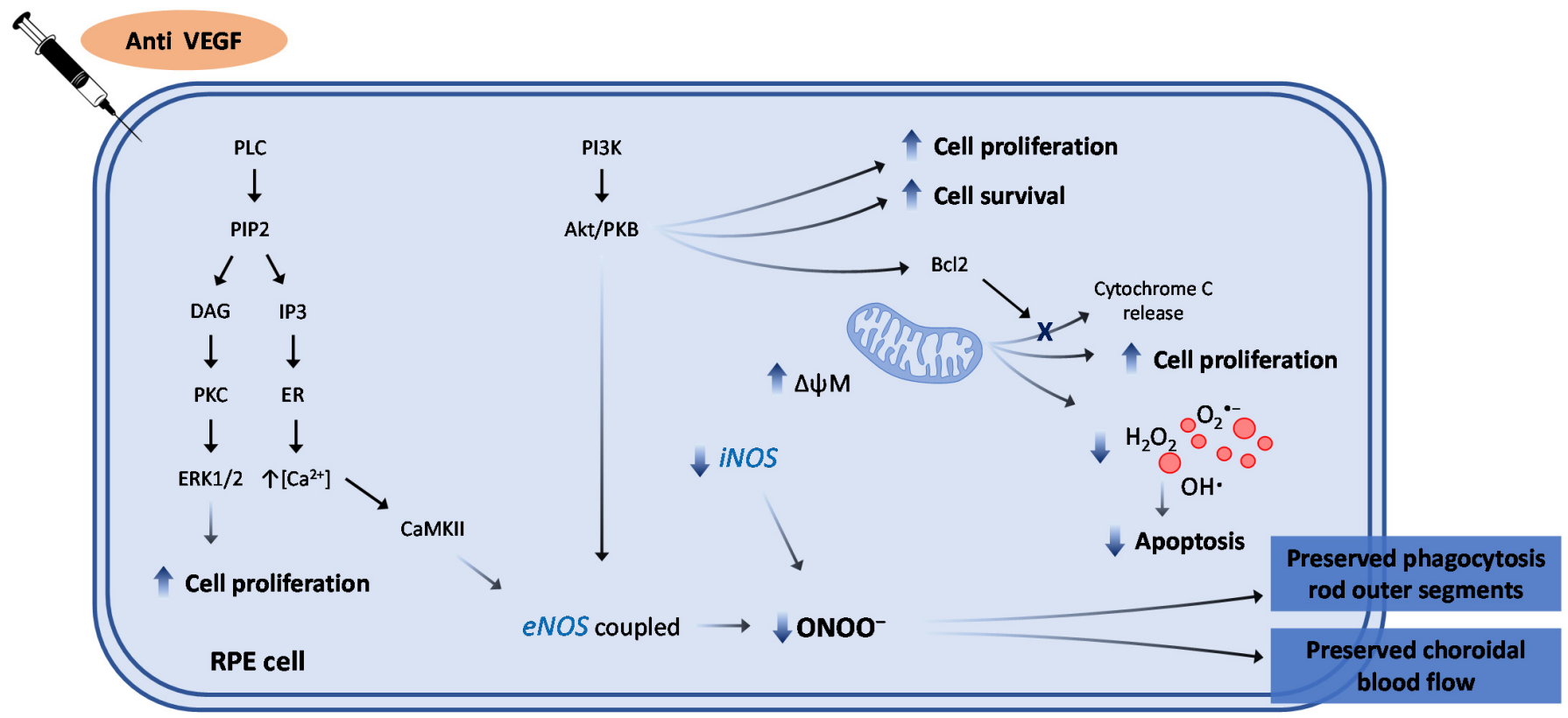

\section{Bruch's membrane}

Figure 5. Schematic representation of the intracellular pathways activated by anti-VEGF agents in AMD. PLC: phospholipase C; PIP2: phosphatidylinositol 4,5-bisphosphate; DAG: diacyl glycerol; IP3: inositol triphosphate; PKC: protein kinase C; ER: endoplasmic reticulum; PI3K: phosphoinositide 3-kinase; PKB: protein kinase B; ERK1/2: extracellular signal-regulated kinase 1/2; CaMKII: calcium/calmodulin-dependent protein kinase II; eNOS: endothelial nitric oxide synthase isoform; iNOS: inducible nitric oxide synthase; $\mathrm{ONOO}^{-}$: peroxinitrites; $\triangle \psi \mathrm{M}$ : mitochondrial membrane potential.

\section{Conclusions}

In the present review, we have highlighted the different pathways involved in the initiation of AMD and in the progression to the late stages of disease in the context of oxidative stress. A growing body of scientific evidence supports the hypothesis that oxidative damage plays a key role in the initiation of AMD pathologic processes, such as drusen formation and RPE changes, with secondary activation of the inflammatory cascade and of mechanisms of cell death. Moreover, the idea that oxidative stress is also directly involved in the process of neovascularization in the late stages of the disease is increasingly gaining ground between researchers. NO contributes to the regulation of choroidal perfusion and the imbalance between NO and RNS observed under pathologic conditions is thought to induce microcirculatory changes in the choroid, both in nonneovascular and nAMD. Anti-VEGF agents have been shown to act against oxidative damage and to have a protective effect on cellular survival by preserving mitochondrial function, the activation of the autophagy defense system and mechanisms mediated by the release of NO. Further research is needed to study new treatments or implement current treatments, with the purpose of better counteracting the damaging effect of oxidative and nitrosative stress in AMD.

Author Contributions: Conceptualization, C.T., S.D.C. and E.G.; validation, all authors; writingoriginal draft preparation, all authors; writing—review and editing, E.G.; supervision, E.G.; All authors have read and agreed to the published version of the manuscript.

Funding: This research received no external funding.

Conflicts of Interest: The authors declare no conflict of interest. 


\section{References}

1. Wong, W.L.; Su, X.; Li, X.; Cheung, C.M.G.; Klein, R.; Cheng, C.; Wong, T.Y. Global prevalence of age-related macular degeneration and disease burden projection for 2020 and 2040: A systematic review and meta-analysis. Lancet Glob. Health 2014, 2, 106-116. [CrossRef]

2. GBD 2019 Blindness and Vision Impairment Collaborators; Vision Loss Expert Group of the Global Burden of Disease Study. Causes of blindness and vision impairment in 2020 and trends over 30 years, and prevalence of avoidable blindness in relation to VISION 2020: The Right to Sight: An analysis for the Global Burden of Disease Study. Lancet Glob. Health 2021, 9, e144-e160. [CrossRef]

3. Ferris, F.L.; Wilkinson, C.P.; Bird, A.; Chakravarthy, U.; Chew, E.; Csaky, K.; Sadda, S.R. Clinical classification of age-related macular degeneration. Ophthalmology 2013, 120, 844-851. [CrossRef] [PubMed]

4. Spaide, R.F.; Jaffe, G.J.; Sarraf, D.; Freund, K.B.; Sadda, S.R.; Staurenghi, G.; Waheed, N.K.; Chakravarthy, U.; Rosenfeld, P.J.; Holz, F.G.; et al. Consensus Nomenclature for Reporting Neovascular Age-Related Macular Degeneration Data: Consensus on Neovascular Age-Related Macular Degeneration Nomenclature Study Group. Ophthalmology 2020, 127, 616-636. [CrossRef] [PubMed]

5. Heesterbeek, T.J.; Lorés-Motta, L.; Hoyng, C.B.; Lechanteur, Y.T.E.; den Hollander, A.I. Risk factors for progression of age-related macular degeneration. Ophthalmic Physiol. Opt. 2020, 40, 140-170. [CrossRef]

6. Colijn, J.M.; Meester, M.; Verzijden, T.; de Breuk, A.; Silva, R.; Merle, B.M.J.; Cougnard-Grégoire, A.; Hoyng, C.B.; Fauser, S.; Coolen, T.; et al. Genetic risk, lifestyle, and AMD in Europe. The EYE-RISK consortium. Ophthalmology 2020. [CrossRef]

7. Lambert, N.G.; ElShelmani, H.; Singh, M.K.; Mansergh, F.C.; Wride, M.A.; Padilla, M.; Keegan, D.; Hogg, R.E.; Ambati, B.K. Risk factors and biomarkers of age-related macular degeneration. Prog. Retin. Eye Res. 2016, 54, 64-102. [CrossRef]

8. Smith, W.; Assink, J.; Klein, R.; Mitchell, P.; Klaver, C.C.; Klein, B.E.; Hofman, A.; Jensen, S.; Wang, J.J.; De Jong, P.T. Risk factors for age-related macular degeneration: Pooled findings from three continents. Ophthalmology 2001, 108, 697-704. [CrossRef]

9. Mitchell, P.; Wang, J.J.; Smith, W.; Leeder, S.R. Smoking and the 5-year incidence of age-related maculopathy: The Blue Mountains Eye Study. Arch. Ophthalmol. 2002, 120, 1357-1363. [CrossRef]

10. Adams, M.K.; Chong, E.W.; Williamson, E.; Aung, K.Z.; Makeyeva, G.A.; Giles, G.G.; English, D.R.; Hopper, J.; Guymer, R.H.; Baird, P.N.; et al. 20/20-Alcohol and age-related macular degeneration. Am. J. Epidemiol. 2012, 176, 289-298. [CrossRef]

11. Fritsche, L.G.; Fariss, R.N.; Stambolian, D.; Abecasis, G.R.; Curcio, C.A.; Swaroop, A. Age-related macular degeneration: Genetics and biology coming together. Annu. Rev. Genom. Hum. Genet. 2014, 15, 151-171. [CrossRef]

12. Tisi, A.; Feligioni, M.; Passacantando, M.; Ciancaglini, M.; Maccarono, R. The impact of oxidative stress on blood-retinal barrier physiology in age-related macular degeneration. Cells 2021, 10, 64. [CrossRef]

13. Park, G.B.; Kim, D. Cigarette smoke-induced EGFR activation promotes Epithelial mesenchymal migration of human retinal pigment Epithelial cells through regulation of the fak-mediated Syk/Src pathway. Mol. Med. Rep. 2018, 17, 3563-3574. [CrossRef] [PubMed]

14. Kunchithapautham, K.; Atkinson, C.; Rohrer, B. Smoke exposure causes endoplasmic reticulum stress and lipid accumulation in retinal pigment epithelium through oxidative stress and complement activation. J. Biol. Chem. 2014, 289, 14534-14546. [CrossRef] [PubMed]

15. Jun, S.; Datta, S.; Wang, L.; Pegany, R.; Cano, M.; Handa, J.T. The impact of lipids, lipid oxidation, and inflammation on AMD, and the potential role of miRNAs on lipid metabolism in the RPE. Exp. Eye Res. 2019, 181, 346-355. [CrossRef]

16. Schick, T.; Ersoy, L.; Lechanteur, Y.T.E.; Saksens, N.T.M.; Hoyng, C.B.; den Hollander, A.I.; Kirchhof, B.; Fauser, S. History of sunlight exposure is a risk factor for age-related macular degeneration. Retina 2016, 36, 787-790. [CrossRef]

17. Sui, G.Y.; Liu, G.C.; Liu, G.Y.; Gao, Y.Y.; Deng, Y.; Wang, W.Y.; Tong, S.H.; Wang, L. Is sunlight exposure a risk factor for age-related macular degeneration? A systematic review and meta-analysis. Br. J. Ophthalmol. 2013, 97, 389-394. [CrossRef] [PubMed]

18. Borras, C.; Canonica, J.; Jorieux, S.; Abache, T.; El Sanharawi, M.; Klein, C.; Delaunay, K.; Jonet, L.; Salvodelli, M.; Naud, M.C.; et al. CFH exerts anti-oxidant effects on retinal pigment epithelial cells independently from protecting against membrane attack complex. Sci. Rep. 2019, 9, 13873. [CrossRef] [PubMed]

19. Weismann, D.; Hartvigsen, K.; Lauer, N.; Bennett, K.L.; Scholl, H.P.N.; Issa, P.C.; Cano, M.; Brandstätter, H.; Tsimikas, S.; Skerka, C.; et al. Complement factor $\mathrm{H}$ binds malondialdehyde epitopes and protects from oxidative stress. Nature 2011, 478, 76-81. [CrossRef]

20. Shaw, P.X.; Zhang, L.; Zhang, M.; Du, H.; Zhao, L.; Lee, C.; Grob, S.; Lim, S.L.; Hughes, G.; Lee, J.; et al. Complement factor H genotypes impact risk of age-related macular degeneration by interaction with oxidized phospholipids. Proc. Natl. Acad. Sci. USA 2012, 109, 13757-13762. [CrossRef]

21. Jones, D.P. Redox theory of aging. Redox Biol. 2015, 5, 71-79. [CrossRef] [PubMed]

22. Handa, J.T. How does the macula protect itself from oxidative stress? Mol. Asp. Med. 2012, 33, 418-435. [CrossRef] [PubMed]

23. Miceli, M.V.; Liles, M.R.; Newsome, D.A. Evaluation of oxidative processes in human pigment epithelial cells associated with retinal outer segment phagocytosis. Exp. Cell Res. 1994, 214, 242-249. [CrossRef]

24. Bhutto, I.; Lutty, G. Understanding age-related macular degeneration (AMD): Relationships between the photoreceptor/retinal pigment epithelium/Bruch's membrane/choriocapillaris complex. Mol. Asp. Med. 2012, 33, 295-317. [CrossRef] [PubMed]

25. Wangsa-Wirawan, N.D.; Linsenmeier, R.A. Retinal oxygen. Fundamental and clinical aspects. Arch. Ophthalmol. 2003, $21,547-557$. [CrossRef] [PubMed] 
26. Strauss, O. The retinal pigment epithelium in visual function. Physiol. Rev. 2005, 85, 845-881. [CrossRef] [PubMed]

27. Marshall, J. The ageing retina: Physiology or pathology. Eye 1987, 1, 282-295. [CrossRef] [PubMed]

28. McLeod, D.S.; Taomoto, M.; Otsuji, T.; Green, W.R.; Sunness, J.S.; Lutty, G.A. Quantifying changes in RPE and choriocapillaris in eyes with age-related macular degeneration. Investig. Ophthalmol. Vis. Sci. 2002, 43, 1986-1993.

29. Korte, G.E.; Repucci, V.; Henkind, P. RPE destruction causes choriocapillary atrophy. Investig. Ophthalmol. Vis. Sci. 1984, 25, 1135-1145.

30. McLeod, D.S.; Grebe, R.; Bhutto, I.; Merges, C.; Baba, T.; Lutty, G.A. Relationship between RPE and choriocapillaris in age-related macular degeneration. Investig. Ophthalmol. Vis. Sci 2009, 50, 4982-4991. [CrossRef]

31. Zarbin, M.A.; Rosenfeld, P.J. Pathway-based therapies for age-related macular degeneration: An integrated survey of emerging treatment alternatives. Retina 2010, 30, 1350-1367. [CrossRef]

32. Querques, G.; Rosenfeld, P.J.; Cavallero, E.; Borrelli, E.; Corvi, F.; Querques, L.; Bandello, F.M.; Zarbin, M.A. Treatment of dry age-related macular degeneration. Ophthalmic Res. 2014, 52, 107-115. [CrossRef] [PubMed]

33. Borrelli, E.; Abdelfattah, N.S.; Uji, A.; Nittala, M.G.; Boyer, D.S.; Sadda, S.R. Postreceptor neuronal loss in intermediate age-related macular degeneration. Am. J. Ophthalmol. 2017, 181,1-11. [CrossRef]

34. Vujosevic, S.; Toma, C.; Villani, E.; Muraca, A.; Torti, E.; Florimbi, G.; Pezzotti, M.; Nucci, P.; De Cillà, S. Quantitative choriocapillaris evaluation in intermediate age-related macular degeneration by swept-source optical coherence tomography angiography. Acta Ophthalmol. 2019, 97, e919-e926. [CrossRef]

35. Grunwald, J.E.; Metelitsina, T.I.; Dupont, J.C.; Ying, G.S.; Maguire, M.G. Reduced foveolar choroidal blood flow in eyes with increasing AMD severity. Investig. Ophthalmol. Vis. Sci 2005, 46, 1033-1038. [CrossRef] [PubMed]

36. Lutty, G.A.; McLeod, D.S.; Bhutto, I.A.; Edwards, M.M.; Seddon, J.M. Choriocapillaris dropout in early age-related macular degeneration. Exp. Eye Res. 2020, 192, 107939. [CrossRef]

37. Seddon, J.M.; McLeod, D.S.; Bhutto, I.A.; Villalonga, M.B.; Silver, R.E.; Wenick, A.S.; Edwards, M.M.; Lutty, G.A. Histopathological Insights into Choroidal Vascular Loss in Clinically Documented Cases of Age-Related Macular Degeneration. JAMA Ophthalmol. 2016, 134, 1272-1280. [CrossRef] [PubMed]

38. Bhutto, I.A.; McLeod, D.S.; Hasegawa, T.; Kim, S.Y.; Merges, C.; Tong, P.; Lutty, G.A. Pigment epithelium-derived factor (PEDF) and vascular endothelial growth factor (VEGF) in aged human choroid and eyes with age-related macular degeneration. Exp. Eye Res. 2006, 82, 99-110. [CrossRef] [PubMed]

39. Bellezza, I. Oxidative Stress in Age-Related Macular Degeneration: Nrf2 as Therapeutic Target. Front. Pharmacol. 2018, 9, 1280. [CrossRef] [PubMed]

40. Chen, M.; Luo, C.; Zhao, J.; Devarajan, G.; Xu, H. Immune regulation in the aging retina. Prog. Retin. Eye Res. 2019, 69, 159-172. [CrossRef]

41. Evans, M.D.; Dizdaroglu, M.; Cooke, M.S. Oxidative DNA damage and disease: Induction, repair and significance. Mutat. Res. 2004, 567, 1-61. [CrossRef] [PubMed]

42. Wu, W.C.; Hu, D.N.; Gao, H.X.; Chen, M.; Wang, D.; Rosen, R.; McCormick, S.A. Subtoxic levels hydrogen peroxide-induced production of interleukin-6 by retinal pigment epithelial cells. Mol. Vis. 2010, 16, 1864-1873.

43. Glotin, A.L.; Debacq-Chainiaux, F.; Brossas, J.Y.; Faussat, A.M.; Treton, J.; Zubielewicz, A.; Toussaint, O.; Mascarelli, F. Prematurely senescent ARPE-19 cells display features of age-related macular degeneration. Free Radic. Biol. Med. 2008, 44, $1348-1361$. [CrossRef] [PubMed]

44. Chaum, E.; Yin, J.; Lang, J.C. Molecular responses transduced by serial oxidative stress in the retinal pigment epithelium: Feedback control modeling of gene expression. Neurochem. Res. 2011, 36, 574-582. [CrossRef] [PubMed]

45. Strunnikova, N.; Zhang, C.; Teichberg, D.; Cousins, S.W.; Baffi, J.; Becker, K.G.; Csaky, K.G. Survival of retinal pigment epithelium after exposure to prolonged oxidative injury: A detailed gene expression and cellular analysis. Investig. Ophthalmol. Vis. Sci. 2004, 45, 3767-3777. [CrossRef] [PubMed]

46. Weigel, A.L.; Handa, J.T.; Hjelmeland, L.M. Microarray analysis of H2O2-, HNE-, or tBH-treated ARPE-19 cells. Free Radic. Biol. Med. 2002, 33, 1419-1432. [CrossRef]

47. Weigel Andrea, L.; Ida, H.; Boylan, S.A.; Hjelmeland, L.M. Acute hyperoxia-induced transcriptional response in the mouse RPE/choroid. Free Radic. Biol. Med. 2003, 35, 465-474. [CrossRef]

48. Lu, L.; Hackett, S.F.; Mincey, A.; Lai, H.; Campochiaro, P.A. Effects of different types of oxidative stress in RPE cells. J. Cell Physiol. 2006, 206, 119-125. [CrossRef]

49. Rabin, D.M.; Rabin, R.L.; Blenkinsop, T.A.; Temple, S.; Stern, J.H. Chronic oxidative stress upregulates Drusen-related protein expression in adult human RPE stem cell-derived RPE cells: A novel culture model for dry AMD. Aging 2013, 5, 51-66. [CrossRef] [PubMed]

50. Imamura, Y.; Noda, S.; Hashizume, K.; Shinoda, K.; Yamaguchi, M.; Uchiyama, S.; Shimizu, T.; Mizushima, Y.; Shirasawa, T.; Tsubota, K. Drusen, choroidal neovascularization, and retinal pigment epithelium dysfunction in SOD1-deficient mice: A model of age-related macular degeneration. Proc. Natl. Acad. Sci. USA 2006, 103, 11282-11287. [CrossRef] [PubMed]

51. Justilien, V.; Pang, J.J.; Renganathan, K.; Zhan, X.; Crabb, J.W.; Kim, S.R.; Sparrow, J.R.; Hauswirth, W.W.; Lewin, A.S. SOD2 knockdown mouse model of early AMD. Investig. Ophthalmol. Vis. Sci. 2007, 48, 4407-4420. [CrossRef]

52. Zhao, Z.; Chen, Y.; Wang, J.; Sternberg, P.; Freeman, M.L.; Grossniklaus, H.E.; Cai, J. Age-related retinopathy in NRF2-deficient mice. PLoS ONE 2011, 6, e19456. [CrossRef] 
53. Hu, P.; Herrmann, R.; Bednar, A.; Saloupis, P.; Dwyer, M.A.; Yang, P.; Qi, X.; Thomas, R.S.; Jaffe, G.J.; Boulton, M.E.; et al. Aryl hydrocarbon receptor deficiency causes dysregulated cellular matrix metabolism and age-related macular degeneration-like pathology. Proc. Natl. Acad. Sci. USA 2013, 110, E4069-E4078. [CrossRef] [PubMed]

54. Kim, S.Y.; Yang, H.J.; Chang, Y.S.; Kim, J.W.; Brooks, M.; Chew, E.Y.; Wong, W.T.; Fariss, R.N.; Rachel, R.A.; Cogliati, T.; et al. Deletion of aryl hydrocarbon receptor AHR in mice leads to subretinal accumulation of microglia and RPE atrophy. Investig. Ophthalmol. Vis. Sci. 2014, 55, 6031-6040. [CrossRef] [PubMed]

55. Sickel, W. Retinal metabolism in dark and light. In Handbook of Sensory Physiology, 1st ed.; Fuortes, M.G.F., Ed.; Springer: Berlin/Heidelberg, Germany, 1972; Volume 7/2, pp. 667-727.

56. Kortuem, K.; Geiger, L.K.; Levin, L.A. Differential susceptibility of retinal ganglion cells to reactive oxygen species. Investig. Ophtalmol. Vis. Sci. 2000, 41, 3176-3183.

57. Beatty, S.; Koh, H.; Phil, M.; Henson, D.; Boulton, M. The role of oxidative stress in the pathogenesis of age-related macular degeneration. Surv. Ophthalmol. 2000, 45, 115-134. [CrossRef]

58. Marquioni-Ramella, M.D.; Suburo, A.M. Photo-damage, photo-protection and age-related macular degeneration. Photochem. Photobiol. Sci. 2015, 14, 1560-1577. [CrossRef] [PubMed]

59. Stefánsson, E.; Geirsdóttir, A.; Sigurdsson, H. Metabolic physiology in age related macular degeneration. Prog. Retin. Eye Res. 2011, 30, 72-80. [CrossRef] [PubMed]

60. Stefánsson, E.; Olafsdottir, O.B.; Eliasdottir, T.S.; Vehmeijer, W.; Einarsdottir, A.B.; Bek, T.; Torp, T.L.; Grauslund, J.; Eysteinsson, T.; Karlsson, R.A.; et al. Retinal oximetry: Metabolic imaging for diseases of the retina and brain. Prog. Retin. Eye Res. 2019, 70, 1-22. [CrossRef]

61. Eells, J.T. Mitochondrial dysfunction in the aging retina. Biology 2019, 8, 31. [CrossRef]

62. Blasiak, J.; Petrovski, G.; Veréb, Z.; Facskó, A.; Kaarniranta, K. Oxidative stress, hypoxia, and autophagy in the neovascular processes of age-related macular degeneration. Biomed. Res. Int. 2014, 2014, 768026. [CrossRef] [PubMed]

63. Roth, F.; Bindewald, A.; Holz, F.G. Keypathophysiologic pathways in age-related macular disease. Graefes Arch. Clin. Exp. Ophthalmol. 2004, 242, 710-716. [CrossRef]

64. Stone, W.L.; Farnsworth, C.C.; Dratz, E.A. A reinvestigation of the fatty acid content of bovine, rat and frog retinal rod outer segments. Exp. Eye Res. 1979, 28, 387-397. [CrossRef]

65. Arstila, A.U.; Smith, M.A.; Trump, B.F. Microsomal lipid peroxidation: Morphological characterization. Science 1972, 175, 530-533. [CrossRef] [PubMed]

66. Sparrow, J.R.; Boulton, M. RPE lipofuscin and its role in retinal pathobiology. Exp. Eye Res. 2005, 80, 595-606. [CrossRef]

67. Tate, D.J., Jr.; Miceli, M.V.; Newsome, D.A. Phagocytosis and $\mathrm{H}_{2} \mathrm{O}_{2}$ induce catalase and metallothionein gene expression in human retinal pigment epithelial cells. Investig. Ophthalmol. Vis. Sci. 1995, 36, 1271-1279.

68. Rózanowska, M.; Jarvis-Evans, J.; Korytowski, W.; Boulton, M.E.; Burke, J.M.; Sarna, T. Blue light-induced reactivity of retinal age pigment. In vitro generation of oxygen-reactive species. J. Biol. Chem. 1995, 270, 18825-18830. [CrossRef]

69. Sparrow, J.R.; Nakanishi, K.; Parish, C.A. The lipofuscin fluorophore A2E mediates blue light-induced damage to retinal pigmented epithelial cells. Investig. Ophthalmol. Vis. Sci. 2000, 41, 1981-1989.

70. Shamsi, F.A.; Boulton, M. Inhibition of RPE lysosomal and antioxidant activity by the age pigment lipofuscin. Investig. Ophthalmol. Vis. Sci. 2001, 42, 3041-3046.

71. Kopitz, J.; Holz, F.G.; Kaemmerer, E.; Schutt, F. Lipids and lipid peroxidation products in the pathogenesis of age-related macular degeneration. Biochimie 2004, 86, 825-831. [CrossRef]

72. Kaidzu, S.; Tanito, M.; Ohira, A.; Umeda, S.; Suzuki, M.; Yoshikawa, Y.; Iwata, T. Immunohistochemical analysis of aldehydemodified proteins in drusen in cynomolgus monkeys (Macaca fascicularis). Exp. Eye Res. 2008, 86, 856-859. [CrossRef]

73. Ethen, C.M.; Reilly, C.; Feng, X.; Olsen, T.W.; Ferrington, D.A. Age-related macular degeneration and retinal protein modification by 4-hydroxy-2-nonenal. Investig. Ophthalmol. Vis. Sci. 2007, 48, 3469-3479. [CrossRef]

74. Tanito, M.; Elliott, M.H.; Kotake, Y.; Anderson, R.E. Protein modifications by 4-hydroxynonenal and 4-hydroxyhexenal in light-exposed rat retina. Investig. Ophthalmol. Vis. Sci. 2005, 46, 3859-3868. [CrossRef] [PubMed]

75. Baskol, G.; Karakucuk, S.; Oner, A.O.; Baskol, M.; Kocer, D.; Mirza, E.; Saraymen, R.; Ustdal, M. Serum paraoxonase 1 activity and lipid peroxidation levels in patients with age-related macular degeneration. Ophthalmologica 2006, 220, 12-16. [CrossRef] [PubMed]

76. Schutt, F.; Bergmann, M.; Holz, F.G.; Kopitz, J. Proteins modified by malondialdehyde, 4-hydroxynonenal, or advanced glycation end products in lipofuscin of human retinal pigment epithelium. Investig. Ophthalmol. Vis. Sci. 2003, 44, 3663-3668. [CrossRef] [PubMed]

77. Totan, Y.; Yagci, R.; Bardak, Y.; Ozyurt, H.; Kendir, F.; Yilmaz, G.; Sahin, S.; Sahin Tig, U. Oxidative macromolecular damage in age-related macular degeneration. Curr. Eye Res. 2009, 34, 1089-1093. [CrossRef] [PubMed]

78. Hollyfield, J.G.; Bonilha, V.L.; Rayborn, M.E.; Yang, X.; Shadrach, K.G.; Lu, L.; Ufret, R.L.; Salomon, R.G.; Perez, V.L. Oxidative damage-induced inflammation initiates age-related macular degeneration. Nat. Med. 2008, 14, 194-198. [CrossRef] [PubMed]

79. Lau, A.; Wang, X.J.; Zhao, F.; Villeneuve, N.F.; Wu, T.; Jiang, T.; Sun, Z.; White, E.; Zhang, D.D. A noncanonical mechanism of Nrf2 activation by autophagy deficiency: Direct interaction between Keap1 and p62. Mol. Cell Biol. 2010, 30, 3275-3285. [CrossRef] 
80. Ye, F.; Kaneko, H.; Hayashi, Y.; Takayama, K.; Hwang, S.J.; Nishizawa, Y.; Kimoto, R.; Nagasaka, Y.; Tsunekawa, T.; Matsuura, T. Malondialdehyde induces autophagy dysfunction and VEGF secretion in the retinal pigment epithelium in age-related macular degeneration. Free Radic. Biol. Med. 2016, 94, 121-134. [CrossRef]

81. Yadav, U.C.; Ramana, K.V. Regulation of NF-kB-induced inflammatory signaling by lipid peroxidation-derived aldehydes. Oxid Med. Cell Longev. 2013, 2013, 690545. [CrossRef]

82. Kim, S.Y.; Kambhampati, S.P.; Bhutto, I.A.; McLeod, D.S.; Lutty, G.A.; Kannan, R.M. Evolution of oxidative stress, inflammation and neovascularization in the choroid and retina in a subretinal lipid induced age-related macular degeneration model. Exp. Eye Res. 2021, 203, 108391. [CrossRef] [PubMed]

83. Zhang, K.; Zhang, L.; Weinreb, R.N. Ophthalmic drug discovery: Novel targets and mechanisms for retinal diseases and glaucoma. Nat. Rev. Drug Discov. 2012, 11, 541-559. [CrossRef] [PubMed]

84. Suzuki, M.; Tsujikawa, M.; Itabe, H.; Du, Z.J.; Xie, P.; Matsumura, N.; Fu, X.; Zhang, R.; Sonoda, K.H.; Egashira, K.; et al. Chronic photo-oxidative stress and subsequent MCP-1 activation as causative factors for age-related macular degeneration. J. Cell Sci. 2012, 125, 2407-2415. [CrossRef] [PubMed]

85. Ma, Q. Role of nrf2 in oxidative stress and toxicity. Annu. Rev. Pharmacol. Toxicol. 2013, 53, 401-426. [CrossRef] [PubMed]

86. Cano, M.; Thimmalappula, R.; Fujihara, M.; Nagai, N.; Sporn, M.; Wang, A.L.; Neufeld, A.H.; Biswal, S.; Handa, J.T. Cigarette smoking, oxidative stress, the anti-oxidant response through Nrf2 signaling, and Age-related Macular Degeneration. Vis. Res. 2010, 50, 652-664. [CrossRef]

87. Chan, T.C.; Wilkinson Berka, J.L.; Deliyanti, D.; Hunter, D.; Fung, A.; Liew, G.; White, A. The role of reactive oxygen species in the pathogenesis and treatment of retinal diseases. Exp. Eye Res. 2020, 201, 108255. [CrossRef]

88. Gao, J.; Liu, R.T.; Cao, S.; Cui, J.Z.; Wang, A.; To, E.; Matsubara, J.A. NLRP3 inflammasome: Activation and regulation in age-related macular degeneration. Mediat. Inflamm. 2015, 2015, 690243. [CrossRef]

89. Kaarniranta, K.; Salminen, A. Age-related macular degeneration: Activation of innate immunity system via pattern recognition receptors. J. Mol. Med. (Berl.) 2009, 87, 117-123. [CrossRef] [PubMed]

90. Piippo, N.; Korhonen, E.; Hytti, M.; Kinnunen, K.; Kaarniranta, K.; Kauppinen, A. Oxidative Stress is the Principal Contributor to Inflammasome Activation in Retinal Pigment Epithelium Cells with Defunct Proteasomes and Autophagy. Cell Physiol. Biochem. 2018, 49, 359-367. [CrossRef]

91. Wang, K.; Yao, Y.; Zhu, X.; Zhang, K.; Zhou, F.; Zhu, L. Amyloid $\beta$ induces NLRP3 inflammasome activation in retinal pigment epithelial cells via NADPH oxidase- and mitochondria-dependent ROS production. J. Biochem. Mol. Toxicol. 2017, 31 , e21887. [CrossRef]

92. Madeira, M.H.; Rashid, K.; Ambrósio, A.F.; Santiago, A.R.; Langmann, T. Blockade of microglial adenosine A2A receptor impacts inflammatory mechanisms, reduces ARPE-19 cell dysfunction and prevents photoreceptor loss in vitro. Sci. Rep. 2018, 8, 2272. [CrossRef]

93. Totsuka, K.; Ueta, T.; Uchida, T.; Roggia, M.F.; Nakagawa, S.; Vavvas, D.G.; Honjo, M.; Aihara, M. Oxidative stress induces ferroptotic cell death in retinal pigment epithelial cells. Exp. Eye Res. 2019, 181, 316-324. [CrossRef] [PubMed]

94. Sharma, A.; Sharma, R.; Chaudhary, P.; Vatsyayan, R.; Pearce, V.; Jeyabal, P.V.; Zimniak, P.; Awasthi, S.; Awasthi, Y.C. 4Hydroxynonenal induces p53-mediated apoptosis in retinal pigment epithelial cells. Arch. Biochem. Biophys. 2008, 480, 85-94. [CrossRef]

95. Hanus, J.; Zhang, H.; Wang, Z.; Liu, Q.; Zhou, Q.; Wang, S. Induction of necrotic cell death by oxidative stress in retinal pigment epithelial cells. Cell Death Dis. 2013, 4, e965. [CrossRef] [PubMed]

96. Hanus, J.; Anderson, C.; Sarraf, D.; Ma, J.; Wang, S. Retinal pigment epithelial cell necroptosis in response to sodium iodate. Cell Death Dis. 2016, 2, 16054. [CrossRef] [PubMed]

97. Li, G.Y.; Fan, B.; Zheng, Y.C. Calcium overload is a critical step in programmed necrosis of ARPE-19 cells induced by highconcentration $\mathrm{H}_{2} \mathrm{O}_{2}$. Biomed. Environ. Sci. 2010, 23, 371-377. [CrossRef]

98. Murakami, Y.; Matsumoto, H.; Roh, M.; Giani, A.; Kataoka, K.; Morizane, Y.; Kayama, M.; Thanos, A.; Nakatake, S.; Notomi, S.; et al. Programmed necrosis, not apoptosis, is a key mediator of cell loss and DAMP-mediated inflammation in dsRNA-induced retinal degeneration. Cell Death Differ. 2014, 21, 270-277. [CrossRef]

99. Yang, M.; So, K.F.; Lam, W.C.; Lo, A.C.Y. Novel Programmed Cell Death as Therapeutic Targets in Age-Related Macular Degeneration? Int. J. Mol. Sci. 2020, 21, 7279. [CrossRef]

100. Juel, H.B.; Faber, C.; Svendsen, S.G.; Vallejo, A.N.; Nissen, M.H. Inflammatory cytokines protect retinal pigment epithelial cells from oxidative stress-induced death. PLoS ONE 2013, 8, e64619. [CrossRef]

101. Malek, G.; Dwyer, M.; McDonnell, D. Exploring the potential role of the oxidant-activated transcription factor aryl hydrocarbon receptor in the pathogenesis of AMD. Adv. Exp. Med. Biol. 2012, 723, 51-59.

102. Blasiak, J.; Pawlowska, E.; Sobczuk, A.; Szczepanska, J.; Kaarniranta, K. The Aging Stress Response and Its Implication for AMD Pathogenesis. Int. J. Mol. Sci. 2020, 21, 8840. [CrossRef] [PubMed]

103. Barot, M.; Gokulgandhi, M.R.; Mitra, A.K. Mitochondrial dysfunction in retinal diseases. Curr. Eye Res. 2011, 36, 1069-1077. [CrossRef] [PubMed]

104. Armstrong, J.S. Mitochondrial membrane permeabilization: The sine qua non for cell death. Bioessays 2006, 28, 253-260. [CrossRef]

105. Green, D.R.; Kroemer, G. The pathophysiology of mitochondrial cell death. Science 2004, 305, 626-629. [CrossRef] [PubMed] 
106. Yaniv, Y.; Juhaszova, M.; Sollott, S.J. Age-related changes of myocardial ATP supply and demand mechanisms. Trends Endocrinol. Metab. 2013, 24, 495-505. [CrossRef]

107. Zorov, D.B.; Bannikova, S.Y.; Belousov, V.V.; Vyssokikh, M.Y.; Zorova, L.D.; Isaev, N.K.; Krasnikov, B.F.; Plotnikov, E.Y. Reactive oxygen and nitrogen species: Friends or foes? Biochemistry 2005, 70, 215-221. [CrossRef]

108. Finkel, T. Signal transduction by reactive oxygen species. J. Cell Biol. 2011, 194, 7-15. [CrossRef]

109. Datta, S.; Cano, M.; Ebrahimi, K.; Wang, L.; Handa, J.T. The impact of oxidative stress and inflammation on RPE degeneration in non-neovascular AMD. Prog. Retin. Eye Res. 2017, 60, 201-218. [CrossRef]

110. Feher, J.; Kovacs, I.; Artico, M.; Cavallotti, C.; Papale, A.; Balacco Gabrieli, C. Mitochondrial alterations of retinal pigment epithelium in age-related macular degeneration. Neurobiol. Aging 2006, 27, 983-993. [CrossRef]

111. Nordgaard, C.L.; Karunadharma, P.P.; Feng, X.; Olsen, T.W.; Ferrington, D.A. Mitochondrial proteomics of the retinal pigment epithelium at progressive stages of age-related macular degeneration. Investig. Ophthalmol. Vis. Sci. 2008, 49, 2848-2855. [CrossRef]

112. Blasiak, J.; Glowacki, S.; Kauppinen, A.; Kaarniranta, K. Mitochondrial and nuclear DNA damage and repair in age-related macular degeneration. Int. J. Mol. Sci. 2013, 14, 2996-3010. [CrossRef] [PubMed]

113. Terluk, M.R.; Kapphahn, R.J.; Soukup, L.M.; Gong, H.; Gallardo, C.; Montezuma, S.R.; Ferrington, D.A. Investigating mitochondria as a target for treating age-related macular degeneration. J. Neurosci. 2015, 35, 7304-7311. [CrossRef] [PubMed]

114. Allio, R.; Donega, S.; Galtier, N.; Nabholz, B. Large variation in the ratio of mitochondrial to nuclear mutation rate across animals: Implications for genetic diversity and the use of mitochondrial DNA as a molecular marker. Mol. Biol. Evol. 2017, 34, $2762-2772$. [CrossRef] [PubMed]

115. Badia, A.; Salas, A.; Duarri, A.; Ferreira-de-Souza, B.; Zapata, M.Á.; Fontrodona, L.; García-Arumí, J. Transcriptomics analysis of $\mathrm{Ccl} 2 / \mathrm{Cx} 3 \mathrm{cr} 1 / \mathrm{Crb}^{\mathrm{rd} 8}$ deficient mice provides new insights into the pathophysiology of progressive retinal degeneration. Exp. Eye Res. 2021, 203, 108424. [CrossRef] [PubMed]

116. Kaarniranta, K.; Uusitalo, H.; Blasiak, J.; Felszeghy, S.; Kannan, R.; Kauppinen, A.; Salminen, A.; Sinha, D.; Ferrington, D. Mechanisms of mitochondrial dysfunction and their impact on age-related macular degeneration. Prog. Retin. Eye Res. 2020, 79, 100858. [CrossRef] [PubMed]

117. Jarrett, S.G.; Lin, H.; Godley, B.F.; Boulton, M.E. Mitochondrial DNA damage and its potential role in retinal degeneration. Prog. Retin. Eye Res. 2008, 27, 596-607. [CrossRef] [PubMed]

118. Liang, F.Q.; Godley, B.F. Oxidative stress-induced mitochondrial DNA damage in human retinal pigment epithelial cells: A possible mechanism for RPE aging and age-related macular degeneration. Exp. Eye Res. 2003, 76, 397-403. [CrossRef]

119. Johansen, T.; Lamark, T. Selective Autophagy: ATG8 Family Proteins, LIR Motifs and Cargo Receptors. J. Mol. Biol. 2020, 432, 80-103. [CrossRef]

120. Mitter, S.K.; Song, C.; Qi, X.; Mao, H.; Rao, H.; Akin, D.; Lewin, A.; Grant, M.; Dunn, W., Jr.; Ding, J.; et al. Dysregulated autophagy in the RPE is associated with increased susceptibility to oxidative stress and AMD. Autophagy 2014, 10, 1989-2005. [CrossRef]

121. Kang, R.; Zeh, H.J.; Lotze, M.T.; Tang, D. The Beclin 1 network regulates autophagy and apoptosis. Cell Death Differ. 2011, 18, 571-580. [CrossRef]

122. Schaaf, M.B.; Keulers, T.G.; Vooijs, M.A.; Rouschop, K.M. LC3/GABARAP family proteins: Autophagy-(un)related functions. FASEB J. 2016, 30, 3961-3978. [CrossRef]

123. Kaarniranta, K.; Tokarz, P.; Koskela, A.; Paterno, J.; Blasiak, J. Autophagy regulates death of retinal pigment epithelium cells in age-related macular degeneration. Cell Biol. Toxicol. 2017, 33, 113-128. [CrossRef]

124. Sukseree, S.; Chen, Y.T.; Laggner, M.; Gruber, F.; Petit, V.; Nagelreiter, I.M.; Mlitz, V.; Rossiter, H.; Pollreisz, A.; Schmidt-Erfurth, U.; et al. Tyrosinase-Cre-Mediated Deletion of the Autophagy Gene Atg7 Leads to Accumulation of the RPE65 Variant M450 in the Retinal Pigment Epithelium of C57BL/6 Mice. PLoS ONE 2016, 11, e0161640. [CrossRef]

125. Zhang, Y.; Cross, S.D.; Stanton, J.B.; Marmorstein, A.D.; Le, Y.Z.; Marmorstein, L.Y. Early AMD-like defects in the RPE and retinal degeneration in aged mice with RPE-specific deletion of Atg5 or Atg7. Mol. Vis. 2017, 23, 228. [CrossRef] [PubMed]

126. Yao, J.; Jia, L.; Khan, N.; Lin, C.; Mitter, S.K.; Boulton, M.E.; Dunaief, J.L.; Klionsky, D.J.; Guan, J.L.; Thompson, D.A.; et al. Deletion of autophagy inducer RB1CC1 results in degeneration of the retinal pigment epithelium. Autophagy 2015, 11, 939-953. [CrossRef] [PubMed]

127. Karlsson, M.; Frennesson, C.; Gustafsson, T.; Brunk, U.T.; Nilsson, S.E.; Kurz, T. Autophagy of iron-binding proteins may contribute to the oxidative stress resistance of ARPE-19 cells. Exp. Eye Res. 2013, 116, 359-365. [CrossRef] [PubMed]

128. Golestaneh, N.; Chu, Y.; Xiao, Y.Y.; Stoleru, G.L.; Theos, A.C. Dysfunctional autophagy in RPE, a contributing factor in age-related macular degeneration. Cell Death Dis. 2018, 8, e2537. [CrossRef] [PubMed]

129. Hyttinen, J.M.T.; Błasiak, J.; Niittykoski, M.; Kinnunen, K.; Kauppinen, A.; Salminen, A. DNA damage response and autophagy in the degeneration of retinal pigment epithelial cells-Implications for age-related macular degeneration (AMD). Ageing Res. Rev. 2017, 36, 64-77. [CrossRef]

130. Brown, E.E.; DeWeerd, A.J.; Ildefonso, C.J.; Lewin, A.S.; Ash, J.D. Mitochondrial oxidative stress in the retinal pigment epithelium (RPE) led to metabolic dysfunction in both the RPE and retinal photoreceptors. Redox Biol. 2019, 24, 101201. [CrossRef]

131. Bienert, G.P.; Møller, A.L.; Kristiansen, K.A.; Schulz, A.; Møller, I.M.; Schjoerring, J.K.; Jahn, T.P. Specific aquaporins facilitate the diffusion of hydrogen peroxide across membranes. J. Biol. Chem. 2007, 282, 1183-1192. [CrossRef] 
132. Holley, A.K.; Bakthavatchalu, V.; Velez-Roman, J.M.; St Clair, D.K. Manganese superoxide dismutase: Guardian of the powerhouse. Int. J. Mol. Sci. 2011, 12, 7114-7162. [CrossRef]

133. Decanini, A.; Nordgaard, C.L.; Feng, X.; Ferrington, D.A.; Olsen, T.W. Changes in select redox proteins of the retinal pigment epithelium in age-related macular degeneration. Am. J. Ophthalmol. 2007, 143, 607-615. [CrossRef]

134. Nguyen, T.; Sherratt, P.J.; Pickett, C.B. Regulatory mechanisms controlling gene expression mediated by the antioxidant response element. Annu. Rev. Pharmacol. Toxicol. 2003, 43, 233-260. [CrossRef]

135. Rangasamy, T.; Cho, C.Y.; Thimmulappa, R.K.; Zhen, L.; Srisuma, S.S.; Kensler, T.W.; Yamamoto, M.; Petrache, I.; Tuder, R.M.; Biswal, S. Genetic ablation of Nrf2 enhances susceptibility to cigarette smoke-induced emphysema in mice. J. Clin. Investig. 2004, 114, 1248-1259. [CrossRef]

136. Thimmulappa, R.K.; Mai, K.H.; Srisuma, S.; Kensler, T.W.; Yamamoto, M.; Biswal, S. Identification of Nrf2-regulated genes induced by the chemopreventive agent sulforaphane by oligonucleotide microarray. Cancer Res. 2002, 62, 5196-5203. [PubMed]

137. Dinkova-Kostova, A.T.; Holtzclaw, W.D.; Kensler, T.W. The role of Keap1 in cellular protective responses. Chem. Res. Toxicol. 2005, 18, 1779-1791. [CrossRef] [PubMed]

138. Kobayashi, M.; Yamamoto, M. Molecular mechanisms activating the Nrf2-Keap1 pathway of antioxidant gene regulation. Antioxid. Redox Signal. 2005, 7, 385-394. [CrossRef]

139. Kansanen, E.; Kuosmanen, S.M.; Leinonen, H.; Levonen, A.L. The Keap1-Nrf2 pathway: Mechanisms of activation and dysregulation in cancer. Redox Biol. 2013, 1, 45-49. [CrossRef]

140. Wakabayashi, N.; Itoh, K.; Wakabayashi, J.; Motohashi, H.; Noda, S.; Takahashi, S.; Imakado, S.; Kotsuji, T.; Otsuka, F.; Roop, D.R.; et al. Keap1-null mutation leads tompostnatal lethality due to constitutive Nrf2 activation. Nat. Genet. 2003, 35, 238-245. [CrossRef] [PubMed]

141. Wang, L.; Kondo, N.; Cano, M.; Ebrahimi, K.; Yoshida, T.; Barnett, B.P.; Biswal, S.; Handa, J.T. Nrf2 signaling modulates cigarette smoke-induced complement activation in retinal pigmented epithelial cells. Free Radic. Biol. Med. 2014, 70, 155-166. [CrossRef]

142. Zhang, Z.Y.; Bao, X.L.; Cong, Y.Y.; Fan, B.; Li, G.Y. Autophagy in Age-Related Macular Degeneration: A Regulatory Mechanism of Oxidative Stress. Oxid. Med. Cell. Longev. 2020, 8, 2896036. [CrossRef] [PubMed]

143. Myeku, N.; Figueiredo-Pereira, M.E. Dynamics of the degradation of ubiquitinated proteins by proteasomes and autophagy: Association with sequestosome 1/p62. J. Biol. Chem. 2011, 286, 22426-22440. [CrossRef] [PubMed]

144. Jain, A.; Lamark, T.; Sjøttem, E.; Larsen, K.B.; Awuh, J.A.; Øvervatn, A.; McMahon, M.; Hayes, J.D.; Johansen, T. p62/SQSTM1 is a target gene for transcription factor NRF2 and creates a positive feedback loop by inducing antioxidant response element-driven gene transcription. J. Biol. Chem. 2010, 285, 22576-22591. [CrossRef]

145. Zhang, M.; Chu, Y.; Mowery, J.; Konkel, B.; Galli, S.; Theos, A.C.; Golestaneh, N. Pgc-1 $\alpha$ repression and high-fat diet induce age-related macular degeneration-like phenotypes in mice. Dis. Model. Mech. 2018, 11, dmm032698. [CrossRef]

146. Felszeghy, S.; Viiri, J.; Paterno, J.J.; Hyttinen, J.M.T.; Koskela, A.; Chen, M.; Leinonen, H.; Tanila, H.; Kivinen, N.; Koistinen, A.; et al. Loss of NRF-2 and PGC-1 $\alpha$ genes leads to retinal pigment epithelium damage resembling dry age-related macular degeneration. Redox Biol. 2019, 20, 1-12. [CrossRef]

147. Dong, A.; Xie, B.; Shen, J.; Yoshida, T.; Yokoi, K.; Hackett, S.F.; Campochiaro, P.A. Oxidative stress promotes ocular neovascularization. J. Cell Physiol. 2009, 219, 544-552. [CrossRef] [PubMed]

148. Klettner, A.; Roider, J. Constitutive and oxidative-stress-induced expression of VEGF in the RPE are differently regulated by different Mitogen-activated protein kinases. Graefes Arch. Clin. Exp. Ophthalmol. 2009, 247, 1487-1492. [CrossRef] [PubMed]

149. Ellis, E.A.; Guberski, D.L.; Somogyi-Mann, M.; Grant, M.B. Increased $\mathrm{H}_{2} \mathrm{O}_{2}$, vascular endothelial growth factor and receptors in the retina of the BBZ/Wor diabetic rat. Free Radic. Biol. Med. 2000, 28, 91-101. [CrossRef]

150. Kannan, R.; Zhang, N.; Sreekumar, P.G.; Spee, C.K.; Rodriguez, A.; Barron, E.; Hinton, D.R. Stimulation of apical and basolateral VEGF-A and VEGF-C secretion by oxidative stress in polarized retinal pigment epithelial cells. Mol. Vis. 2006, 12, 1649-1659. [PubMed]

151. Wang, H.; Geisen, P. The role of rpe cell-associated vegf189 in choroidal endothelial cell transmigration across the rpe. Investig. Ophthalmol. Vis. Sci. 2011, 52, 570-578. [CrossRef] [PubMed]

152. Brown, E.E.; Lewin, A.S.; Ash, J.D. Mitochondria: Potential Targets for Protection in Age-Related Macular Degeneration. Adv. Exp. Med. Biol. 2018, 1074, 11-17. [PubMed]

153. Monaghan-Benson, E.; Hartmann, J.; Vendrov, A.E.; Budd, S.; Byfield, G.; Parker, A.; Ahmad, F.; Huang, W.; Runge, M.; Burridge, K.; et al. The role of vascular endothelial growth factor-induced activation of NADPH oxidase in choroidal endothelial cells and choroidal neovascularization. Am. J. Pathol. 2010, 177, 2091-2102. [CrossRef] [PubMed]

154. Wang, H.; Yang, Z.; Jiang, Y.; Hartnett, M.E. Endothelial NADPH oxidase 4 mediates vascular endothelial growth factor receptor 2-induced intravitreal neovascularization in a rat model of retinopathy of prematurity. Mol. Vis. 2014, 20, 231-241. [PubMed]

155. Ushio-Fukai, M. Redox signaling in angiogenesis: Role of nadph oxidase. Cardiovasc. Res. 2006, 71, 226-235. [CrossRef]

156. Chen, C.C.; Chow, M.P. Flavonoids inhibit tumor necrosis factor-alpha-induced up-regulation of intercellular adhesion molecule-1 (icam-1) in respiratory epithelial cells through activator protein-1 and nuclear factor-kappab: Structure-activity relationships. Mol. Pharm. 2004, 66, 683-693.

157. Nagata, M. Inflammatory cells and oxygen radicals. Curr. Drug Targets Inflamm. Allergy 2005, 4, 503-504. [CrossRef]

158. 1-Shabrawey, M.; Rojas, M. Role of nadph oxidase in retinal vascular inflammation. Investig. Ophthalmol. Vis. Sci. 2008, 49, 3239-3244. [CrossRef] 
159. Ushio-Fukai, M. Vegf signaling through nadph oxidase-derived ros. Antioxid. Redox Signal. 2007, 9, 731-739. [CrossRef]

160. Ruan, Y.; Jiang, S.; Gericke, A. Age-Related Macular Degeneration: Role of Oxidative Stress and Blood Vessels. Int. J. Mol. Sci. 2021, 22, 1296. [CrossRef] [PubMed]

161. Shen, X.L.; Jia, J.H.; Zhao, P.; Fan, R.; Pan, X.Y.; Yang, H.M.; Liu, L. Changes in blood oxidative and antioxidant parameters in a group of Chinese patients with age-related macular degeneration. J. Nutr. Health Aging 2012, 16, 201-204. [CrossRef]

162. Othman, A.; Ahmad, S.; Megyerdi, S.; Mussell, R.; Choksi, K.; Maddipati, K.R.; Elmarakby, A.; Rizk, N.; Al-Shabrawey, M. 12/15-Lipoxygenase-derived lipid metabolites induce retinal endothelial cell barrier dysfunction: Contribution of NADPH oxidase. PLoS ONE 2013, 8, e57254. [CrossRef] [PubMed]

163. Zor, R.K.; Erşan, S.; Küçük, E.; Yıldırım, G.; Sarı, İ. Serum malondialdehyde, monocyte chemoattractant protein-1, and vitamin C levels in wet type age-related macular degeneration patients. Ther. Adv. Ophthalmol. 2020, 12, 2515841420951682. [CrossRef]

164. Bergmann, M.; Holz, F.; Kopitz, J. Lysosomal stress and lipid peroxidation products induce VEGF-121 and VEGF-165 expression in ARPE-19 cells. Graefes Arch. Clin. Exp. Ophthalmol. 2011, 249, 1477-1483. [CrossRef] [PubMed]

165. Matsuura, T.; Takayama, K.; Kaneko, H.; Ye, F.; Fukukita, H.; Tsunekawa, T.; Kataoka, K.; Hwang, S.J.; Nagasaka, Y.; Ito, Y.; et al. Nutritional Supplementation Inhibits the Increase in Serum Malondialdehyde in Patients with Wet Age-Related Macular Degeneration. Oxid Med. Cell Longev. 2017, 2017, 9548767. [CrossRef]

166. Demontis, G.C.; Longoni, B.; Marchiafava, P.L. Molecular steps involved in light-induced oxidative damage to retinal rods. Investig. Ophthalmol. Vis. Sci. 2002, 43, 2421-2427.

167. Tisi, A.; Parete, G.; Flati, V.; Maccarone, R. Up-regulation of pro-angiogenic pathways and induction of neovascularization by an acute retinal light damage. Sci. Rep. 2020, 10, 6376. [CrossRef]

168. Murakami, Y.; Nakabeppu, Y.; Sonoda, K.H. Oxidative Stress and Microglial Response in Retinitis Pigmentosa. Int. J. Mol. Sci. 2020, 21, 7170. [CrossRef] [PubMed]

169. Santiago, A.R.; Baptista, F.I.; Santos, P.F.; Cristóvão, G.; Ambrósio, A.F.; Cunha, R.A.; Gomes, C.A. Role of microglia adenosine $\mathrm{A}(2 \mathrm{~A})$ receptors in retinal and brain neurodegenerative diseases. Mediat. Inflamm. 2014, 2014, 465694. [CrossRef]

170. Hurst, J.; Kuehn, S.; Jashari, A.; Tsai, T.; Bartz-Schmidt, K.U.; Schnichels, S.; Joachim, S.C. A novel porcine ex vivo retina culture model for oxidative stress induced by $\mathrm{H}_{2} \mathrm{O}_{2}$. Altern. Lab. Anim. 2017, 45, 11-25. [CrossRef]

171. Alderton, W.K.; Cooper, C.E.; Knowles, R.G. Nitric oxide synthases: Structure, function and inhibition. Biochem. J. 2001, 357, 593-615. [CrossRef]

172. Vielma, A.H.; Retamal, M.A.; Schmachtenberg, O. Nitric oxide signaling in the retina: What have we learned in two decades? Brain Res. 2012, 1430, 112-125. [CrossRef]

173. Knowles, R.G.; Moncada, S. Nitric oxide synthases in mammals. Biochem. J. 1994, 298, 249-258. [CrossRef]

174. Goldstein, I.M.; Ostwald, P.; Roth, S. Nitric oxide: A review of its role in retinal function and disease. Vis. Res. 1996, 36, 2979-2994. [CrossRef]

175. Cantó, A.; Olivar, T.; Romero, F.J.; Miranda, M. Nitrosative Stress in Retinal Pathologies: Review. Antioxidants 2019, 8, 543. [CrossRef]

176. Sripathi, S.R.; He, W.; Um, J.Y.; Moser, T.; Dehnbostel, S.; Kindt, K.; Goldman, J.; Frost, M.C.; Jahng, W.J. Nitric oxide leads to cytoskeletal reorganization in the retinal pigment epithelium under oxidative stress. Adv. Biosci. Biotechnol. 2012, 3, 1167-1178. [CrossRef] [PubMed]

177. Bhutto, I.A.; Baba, T.; Merges, C.; McLeod, D.S.; Lutty, G.A. Low nitric oxide synthases (NOSs) in eyes with age-related macular degeneration (AMD). Exp. Eye Res. 2010, 90, 155-167. [CrossRef]

178. Friedman, E. A hemodynamic model of the pathogenesis of age-related macular degeneration. Am. J. Ophthalmol. 1997, 124, 677-682. [CrossRef]

179. Grunwald, J.E.; Hariprasad, S.M.; DuPont, J. Effect of aging on foveolar choroidal circulation. Arch. Ophthalmol. 1998, 116, 150-154. [CrossRef] [PubMed]

180. Martínez-Ruiz, A.; Cadenas, S.; Lamas, S. Nitric oxide signaling: Classical, less classical, and nonclassical mechanisms. Free Radic. Biol. Med. 2011, 51, 17-29. [CrossRef] [PubMed]

181. Knott, A.B.; Bossy-Wetzel, E. Nitric oxide in health and disease of the nervous system. Antioxid. Redox Signal. 2009, 11, 541-554. [CrossRef] [PubMed]

182. Totan, Y.; Koca, C.; Erdurmuş, M.; Keskin, U.; Yiğitoğlu, R. Endothelin-1 and Nitric Oxide Levels in Exudative Age-Related Macular Degeneration. J. Ophthalmic. Vis. Res. 2015, 10, 151-154.

183. Förstermann, U.; Sessa, W.C. Nitric oxide synthases: Regulation and function. Eur. Heart J. 2012, 33, 829-837. [CrossRef] [PubMed]

184. Crabtree, M.J.; Brixey, R.; Batchelor, H.; Hale, A.B.; Channon, K.M. Integrated redox sensor and effector functions for tetrahydrobiopterin- and glutathionylation-dependent endothelial nitric-oxide synthase uncoupling. J. Biol. Chem. 2013, 288, 561-569. [CrossRef]

185. McLeod, D.S.; Baba, T.; Bhutto, I.A.; Lutty, G.A. Co-expression of endothelial and neuronal nitric oxide synthases in the developing vasculatures of the human fetal eye. Graefe's Arch. Clin. Exp. Ophthalmol. 2012, 250, 839-848. [CrossRef] [PubMed]

186. Tekmen-Clark, M.; Gleason, E. Nitric oxide production and the expression of two nitric oxide synthases in the avian retina. Vis. Neurosci. 2013, 30, 91-103. [CrossRef] [PubMed]

187. Haverkamp, S.; Eldred, W.D. Localization of nNOS in photoreceptor, bipolar and horizontal cells in turtle and rat retinas. Neuroreport 1998, 9, 2231-2235. [CrossRef] [PubMed] 
188. Giove, T.J.; Deshpande, M.M.; Eldred, W.D. Identification of alternate transcripts of neuronal nitric oxide synthase in the mouse retina. J. Neurosci. Res. 2009, 87, 3134-3142. [CrossRef] [PubMed]

189. Pang, J.J.; Gao, F.; Wu, S.M. Light responses and morphology of bNOS-immunoreactive neurons in the mouse retina. J. Comp. Neurol. 2010, 518, 2456-2474. [CrossRef]

190. Blom, J.; Give, T.; Deshpande, M.; Eldred, W.D. Characterization of nitric oxide signaling pathways in the mouse retina. J. Comp. Neurol. 2012, 520, 4204-4217. [CrossRef]

191. Waldman, S.A.; Murad, F. Cyclic GMP synthesis and function. Pharmacol. Rev. 1987, 39, 163-196.

192. Schmetterer, L.; Polak, K. Role of nitric oxide in the control of ocular blood flow. Prog. Retin. Eye Res. 2001, 20, 823-847. [CrossRef]

193. Stringham, J.M.; Stringham, N.T. Nitric oxide and lutein: Function, performance, and protection of neural tissue. Foods 2015, 4, 678-689. [CrossRef] [PubMed]

194. Sennlaub, F.; Courtois, Y.; Goureau, O. Inducible nitric oxide synthase mediates the change from retinal to vitreal neovascularization in ischemic retinopathy. J. Clin. Investig. 2001, 107, 717-725. [CrossRef] [PubMed]

195. Zhang, M.; Zhou, J.; Marshall, B.; Xin, H.; Atherton, S.S. Lack of iNOS facilitates MCMV spread in the retina. Investig. Ophthalmol. Vis. Sci. 2007, 48, 285-292. [CrossRef]

196. Yang, L.P.; Li, Y.; Zhu, X.A.; Tso, M.O. Minocycline delayed photoreceptor death in rds mice through iNOS-dependent mechanism. Mol. Vis. 2007, 13, 1073-1082. [PubMed]

197. Papapetropoulos, A.; García-Cardeña, G.; Madri, J.A.; Sessa, W.C. Nitric oxide production contributes to the angiogenic properties of vascular endothelial growth factor in human endothelial cells. J. Clin. Investig. 1997, 100, 3131-3139. [CrossRef]

198. McLaren, A.T.; Marsden, P.A.; Mazer, C.D.; Baker, A.J.; Stewart, D.J.; Tsui, A.K.; Li, X.; Yucel, Y.; Robb, M.; Boyd, S.R.; et al. Increased expression of HIF-1alpha, nNOS, and VEGF in the cerebral cortex of anemic rats. Am. J. Physiol. Regul. Integr. Comp. Physiol. 2007, 292, R403-R414. [CrossRef]

199. Bernatchez, P.N.; Bauer, P.M.; Yu, J.; Prendergast, J.S.; He, P.; Sessa, W.C. Dissecting the molecular control of endothelial NO synthase by caveolin-1 using cell-permeable peptides. Proc. Natl. Acad. Sci. USA 2005, 102, 761-766. [CrossRef]

200. Duda, D.G.; Fukumura, D.; Jain, R.K. Role of eNOS in neovascularization: NO for endothelial progenitor cells. Trends Mol. Med. 2004, 10, 143-145. [CrossRef]

201. Hattenbach, L.O.; Falk, B.; Nürnberger, F.; Koch, F.H.; Ohrloff, C. Detection of inducible nitric oxide synthase and vascular endothelial growth factor in choroidal neovascular membranes. Ophthalmologica 2002, 216, 209-214. [CrossRef]

202. Ando, A.; Yang, A.; Nambu, H.; Campochiaro, P.A. Blockade of nitric-oxide synthase reduces choroidal neovascularization. Mol. Pharmacol. 2002, 62, 539-544. [CrossRef] [PubMed]

203. Jiang, H.; Wu, M.; Liu, Y.; Song, L.; Li, S.; Wang, X.; Zhang, Y.F.; Fang, J.; Wu, S. Serine racemase deficiency attenuates choroidal neovascularization and reduces nitric oxide and VEGF levels by retinal pigment epithelial cells. J. Neurochem. 2017, 143, 375-388. [CrossRef] [PubMed]

204. Lum, F.; Feder, R.S.; McLeod, S.D.; Parke, D.W., 2nd. The Preferred Practice Pattern Guidelines in Ophthalmology. Ophthalmology 2016, 123, 928-929. [CrossRef] [PubMed]

205. De Cillà, S.; Farruggio, S.; Vujosevic, S.; Raina, G.; Filippini, D.; Gatti, V.; Clemente, N.; Mary, D.; Vezzola, D.; Casini, G.; et al. Anti-Vascular Endothelial Growth Factors Protect Retinal Pigment Epithelium Cells Against Oxidation by Modulating Nitric Oxide Release and Autophagy. Cell Physiol. Biochem. 2017, 42, 1725-1738. [CrossRef]

206. Malik, D.; Tarek, M.; Caceres del Carpio, J.; Ramirez, C.; Boyer, D.; Kenney, M.C.; Kuppermann, B.D. Safety profiles of anti-VEGF drugs: Bevacizumab, ranibizumab, aflibercept and ziv-aflibercept on human retinal pigment epithelium cells in culture. $\mathrm{Br}$. $J$. Ophthalmol. 2014, 98 (Suppl. 1), i11-i16. [CrossRef]

207. Sheu, S.J.; Chao, Y.M.; Liu, N.C.; Chan, J.Y. Differential effects of bevacizumab, ranibizumab and aflibercept on cell viability, phagocytosis and mitochondrial bioenergetics of retinal pigment epithelial cell. Acta Ophthalmol. 2015, 93, e631-e643. [CrossRef] [PubMed]

208. Gemenetzi, M.; Lotery, A.J.; Patel, P.J. Risk of geographic atrophy in age-related macular degeneration patients treated with intravitreal anti-VEGF agents. Eye (Lond.) 2017, 31, 1-9. [CrossRef]

209. Lois, N.; McBain, V.; Abdelkader, E.; Scott, N.W.; Kumari, R. Retinal pigment epithelial atrophy in patients with exudative age-related macular degeneration undergoing anti-vascular endothelial growth factor therapy. Retina 2013, 33, 13-22. [CrossRef]

210. Grunwald, J.E.; Pistilli, M.; Daniel, E.; Ying, G.S.; Pan, W.; Jaffe, G.J.; Toth, C.A.; Hagstrom, S.A.; Maguire, M.G.; Martin, D.F. Comparison of Age-Related Macular Degeneration Treatments Trials Research Group. Incidence and Growth of Geographic Atrophy during 5 Years of Comparison of Age-Related Macular Degeneration Treatments Trials. Ophthalmology 2017, 124, 97-104. [CrossRef]

211. Chakravarthy, U.; Harding, S.P.; Rogers, C.A.; Downes, S.M.; Lotery, A.J.; Culliford, L.A.; Reeves, B.C. IVAN study investigators: Alternative treatments to inhibit VEGF in age-related choroidal neovascularisation: 2-year findings of the IVAN randomised controlled trial. Lancet 2013, 382, 1258-1267. [CrossRef]

212. Bhisitkul, R.B.; Mendes, T.S.; Rofagha, S.; Enanoria, W.; Boyer, D.S.; Sadda, S.R.; Zhang, K. Macular atrophy progression and 7-year vision outcomes in subjects from the ANCHOR, MARINA, and HORIZON studies: The SEVEN-UP study. Am. J. Ophthalmol. 2015, 159, 915-924. [CrossRef] [PubMed] 
213. Wons, J.; Wirth, M.A.; Graf, N.; Becker, M.D.; Michels, S. Comparison of progression rate of retinal pigment epithelium loss in patients with neovascular age-related macular degeneration treated with Ranibizumab and Aflibercept. J. Ophthalmol. 2017, 2017, 7432739. [CrossRef] [PubMed]

214. De Cillà, S.; Farruggio, S.; Cocomazzi, G.; Mary, D.; Alkabes, M.; Rossetti, L.; Vujosevic, S.; Grossini, E. Aflibercept and Ranibizumab Modulate Retinal Pigment Epithelial Cells Function by Acting on Their Cross Talk with Vascular Endothelial Cells. Cell Physiol. Biochem. 2020, 54, 161-179. [PubMed] 